\title{
LSE
}

LSE ‘Europe in Question' Discussion Paper Series

\section{It's not about the money! \\ EU funds, local opportunities, and the Brexit vote}

Riccardo Crescenzi, Marco Di Cataldo, and Mara Giua

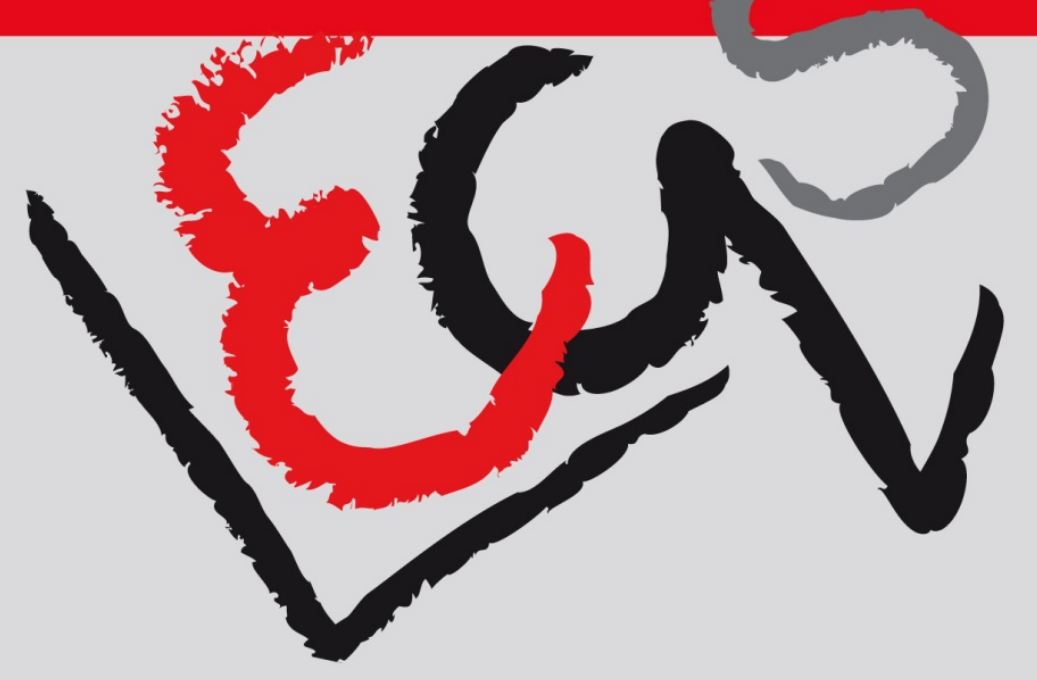




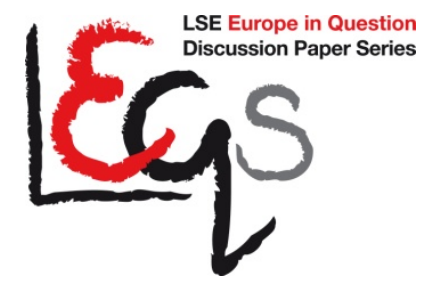

\author{
Editorial Board \\ Dr Bob Hancké \\ Dr Vassilis Monastiriotis \\ Dr Sonja Avlijas \\ Dr Cristóbal Garibay-Petersen \\ Dr Pieter Tuytens \\ Mr Toon Van Oberbeke
}

All views expressed in this paper are those of the author and do not necessarily represent the views of the editors or the LSE.

(C) Riccardo Crescenzi, Marco Di Cataldo, and Mara Giua

Eqs 


\title{
It's not about the money! \\ EU funds, local opportunities, and the Brexit vote
}

\author{
Riccardo Crescenzi *, Marco Di Cataldo **, \\ and Mara Giua ***
}

\begin{abstract}
Growing Euroscepticism across the European Union (EU) leaves open questions as to what citizens expect to gain from EU Membership and what influences their dissent for the EU integration project. This paper looks at EU Structural Funds, one of the largest and most visible expenditure items in the EU budget, to test the impact of EU money on electoral support for the EU. By leveraging the Referendum on Brexit hold in the United Kingdom, a spatial RDD analysis offers causal evidence that EU money does not influence citizens' support for the EU. Conversely, the analysis shows that EU funds contribute to mitigate Euroscepticism only where they are coupled with tangible improvements in the local labour market conditions. In order to gain support from its citizens, the European Union needs to produce tangible impacts, generating opportunities at the local level where these are felt the most by voters.
\end{abstract}

Keywords: Europe, EU funds, Cohesion Policy, Brexit, Euroscepticism, RDD

JEL Codes: R58, D72, P16

* Department of Geography and Environment, London School of Economics Email: R.Crescenzi@Ise.ac.uk

** Department of Economics, Ca' Foscari University of Venice and Department of Geography and Environment, London School of Economics

Email: M.Di-Cataldo@lse.ac.uk

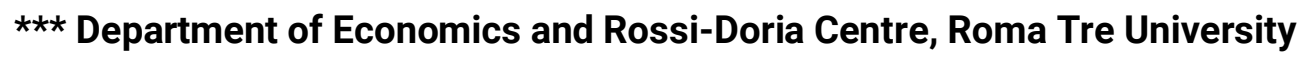

Email: Mara.Giua@uniroma3.it 


\section{Table of Contents}

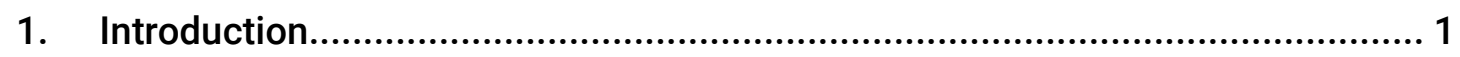

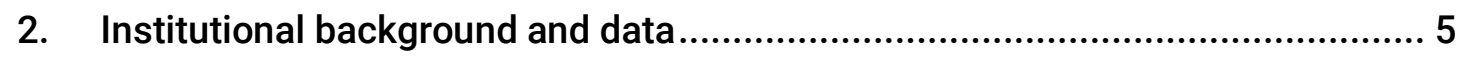

2.1 EU Cohesion Policy in the UK at the time of the Referendum on Brexit.......... 5

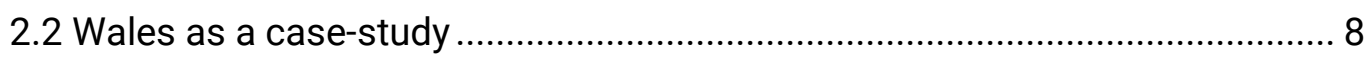

2.3 Data

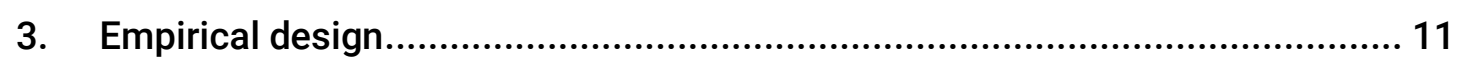

3.1 Identification strategy and empirical models ............................................... 11

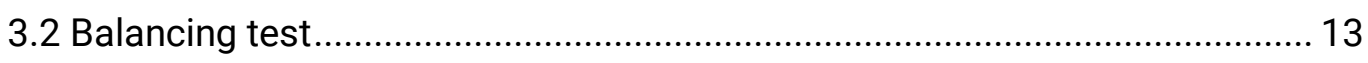

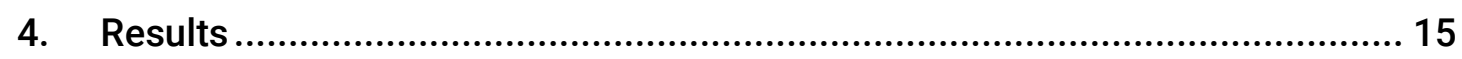

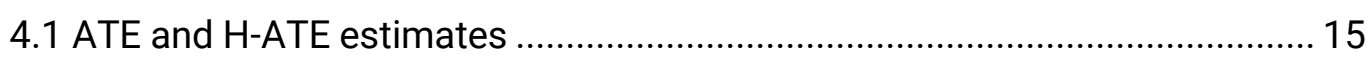

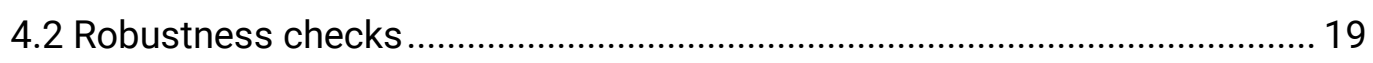

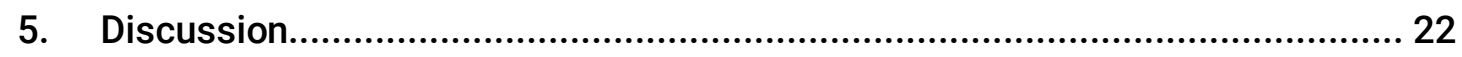

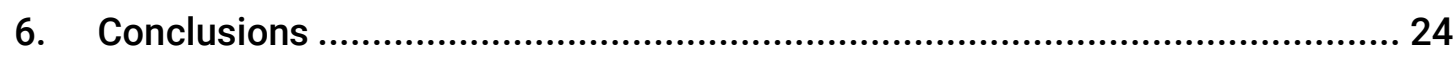

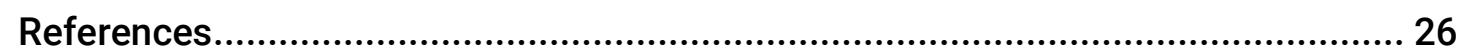

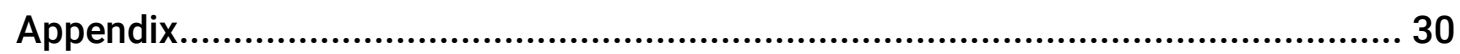

\section{Acknowledgments}

We are grateful to Guglielmo Barone, Felipe Carozzi, Swati Dhingra, Peter Egger, Steve Gibbons, Vicente Royuela, and all seminar/conference participants at University of Barcelona (2017 AQR workshop), University of Rome La Sapienza (CERUP conference), LSE, Cardiff University, Polytechnic of Milan, the 2018 ERSA Congress in Cork, the RSA Winter Conference in London, the National Institute for Economic and Social Research. We thank Martin Rosenbaum at the BBC Political Programmes for sharing the data on Brexit Referendum results at ward level and Julia Bachtroegler for sharing the data on EU funds' beneficiaries in Wales. All errors and omissions are our own.

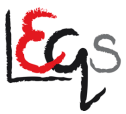




\section{It's not about the money! EU funds, local opportunities, and the Brexit vote}

\section{Introduction}

Anti-systemic political movements have emerged in recent years in a large number of countries across the globe. These parties generally fuel their public support with antielites and anti-establishment rhetoric which in Europe often translates into a strong critique to the European Union (EU) and its institutions. The EU is regarded by the supporters of anti-system movements as distant from the real day-to-day economic challenges of the citizens and as a binding constraint to the capacity of national governments to deliver a more equitable distribution of prosperity. The inability of mainstream politics - of which the EU is seen as a natural expression - to deliver timely and credible answers to the economic needs of large strata of the electorate has been linked to electoral behaviour by a growing body of research (Rodrik, 2018; Colantone and Stanig, 2018; Rodriguez-Pose, 2018; Guiso et al., 2018; Dijkstra et al., 2019). However, it remains unclear how the concrete actions of the EU can practically make a difference to the economic prospects of millions of EU citizens and, through its visible impacts, influence their electoral preferences. Economic theory unveils a number of benefits from the the process of economic integration allowed for by the EU (Baldwin and Wyplosz, 2015). However, the majority of these benefits materialise through adjustments in prices and quantities that are difficult for citizens to link to EU 
membership. Conversely, a set of concrete policy actions are intended to visibly and clearly impact the economic opportunities available to EU citizens. Among those the lion's share of financial resources goes to regional development interventions under the EU Cohesion Policy (Begg, 2008; Bachtler 2017).

While some evidence has been produced to show that financial disbursement through EU Cohesion funds is related to lower Eurosceptic feelings (Osterloh, 2011; Borin et al., 2018; Albanese et al., 2019), other studies are more critical of any direct voting impacts produced by European regional policy (Bachtrogler and Oberhofer, 2018; Fidmurc et al. 2019). This suggests that the role played by EU transfers for the development of pro-Europe attitudes is highly heterogeneous. What makes EU Cohesion resources spread 'love' for the European Union remains to be explored.

Under what conditions (if at all) can EU Cohesion Policy influence support for the European Union? Is the capacity to deliver enhanced economic opportunities in the areas targeted by Cohesion Policy that pays off in the ballots? If the fundamental drive for anti-system votes rests on economic motivations, improvements in local economic conditions experienced by voters in beneficiary areas should - ceteris paribus improve their preferences for EU integration.

We address these research questions by focusing on the context offering arguably the most limpid case of democratic vote either in favour or against the European Union, the 2016 United Kingdom Referendum on EU membership. The Brexit vote represents the ideal setting to investigate the impact of EU funds on Euroscepticism, not only for the nature of the vote being explicitly and uniquely centred on the $\mathrm{EU}^{1}$, but also because in the UK some areas have received very large proportions of financial aid in the form of EU Structural Funds over the last years. In these places, voters at the 2016

\footnotetext{
1 While any election featuring Eurosceptic parties enables voters to express anti-EU preferences, what makes the Brexit Referendum unique is that all voters opting for 'Leave' even if not explicitly driven by resentments against the EU - expressed a clear and unambiguously Eurosceptic choice. Differently, votes for anti-Europe parties at national elections may be completely unrelated with their Eurosceptic platform.
} 
Referendum were not just choosing the future of their country within or outside the $\mathrm{EU}$, but they were also expressing their preference on whether to retain EU financial support.

The impact of EU policies on the Referendum results is estimated by adopting a boundary RDD methodology. We exploit the border between a region classified as 'in highest need of financial help' by the EU at the time of the vote, West Wales and The Valley, and a region receiving a much lower intensity of EU aid, East Wales. To investigate the presence of a causal link between Cohesion Policy and 'Remain' votes, we compare voting outcomes for micro-aggregated units (electoral wards) on the two sides of the border.

Our results document that EU Cohesion funds help 'spreading love' for the EU only if citizens witness clear improvements in their living standards during the funding period. Public support for EU Membership is found to be more sustained in areas receiving higher shares of EU funds and - at the same time - witnessing larger improvements in local labour market conditions. Conversely, EU funding per se appears to be unable to systematically influence voting behaviour.

We capture the economic dynamism of local areas in the pre-Brexit Referendum period through the decrease in the unemployment rate over the period in which the case-study region, West Wales and the Valley, has had access to the highest proportion of development funds from the EU. We find evidence that local areas receiving higher proportions of EU funds and displaying stronger dynamism in their labour market are comparatively more likely to vote in favour of remaining in the European Union.

Therefore, in line with the literature assigning a key role to socio-economic dynamics in shaping Eurosceptic and populistic votes (Colantone and Stanig, 2018; RodriguezPose, 2018; Guiso et al., 2018), our evidence supports the idea that the economic dynamism of local areas mediates the role of EU Structural Funds for Eurosceptic preferences. Taken together, these results indicate that voting preferences of citizens 
are not responsive to financial assistance, but rather to tangible improvements in their daily life, such as new employment opportunities.

This paper relates to different strands of literature. First, it contributes to the rich literature on the impact of Cohesion Policy (e.g. Becker et al., 2010; 2013; 2018), and more specifically the growing, yet still underexplored field of research linking EU funds with the public support for the European Union (e.g. Capello and Perucca, 2017; Bachtler and Mendez, 2017; Dellmuth and Chalmers, 2018; Bachtrogler and Oberhofer, 2018; Borin et al., 2019; Fidrmuc et al, 2019). The mixed evidence emerging from these recent studies leaves the issue of whether areas receiving higher proportions of EU Structural Funds develop a more favourable of Europe because of EU financial help still unsolved. In addition, this literature is silent on whether the effect of EU funding on public support towards the EU materialises under key conditions in place in the territories where public investment through Cohesion Policy takes place. Our contribution aims to assess the impact of EU funds by adopting counterfactual methodologies allowing to uncover clear causal impacts: our focus on the UK context lends itself to this type of analysis due to the Referendum on EU membership held in the country in 2016.

Besides contributing to the study of how Cohesion Policy may affect Euroscepticism, our analysis adds to the literature on the determinants of the Brexit vote. Understanding the reasons that brought the UK population to favour a 'Leave' vote has been the subject of many recent studies. Among the empirical works produced to analyse Brexit determinants (e.g. Hobolt and Wratil 2016; Scruton 2016; Clarke and Whittaker 2016; Harris and Charlton 2017), it is worth noting how several recent contributions have highlighted the primary role of economic conditions faced by voters to explain the Referendum result (Becker et al., 2016; Los et al., 2017; Crescenzi et al., 2018; Colantone and Stanig, 2018; Alabrese et al., 2019). As such, it may expected that EU policies - having enhanced the economic performance of UK poorer regions (Di Cataldo, 2017; Di Cataldo and Monastiriotis, 2019) - may influence the political preferences of voters as well. The works focusing specifically on the relationship 
between EU funds and Brexit Referendum have obtained mixed results. They either report a significant association, suggesting that areas receiving more money from the EU have voted Remain more (Huggins, 2018) or report no significant relationship (Fidrmuc et al., 2019). These studies, however, are performed for relatively large aggregated units (NUTS3 or NUTS2 regions) and without attempting to identify causal impacts. In addition, the divergent results might suggest the omission of more fundamental local factors mediating the impact of EU funds on electoral support for the EU.

More broadly, the paper speaks to the literature analysing the causes of antiestablishment, extremist and populist votes, which has been booming in recent years (e.g. Barone et al., 2016; Autor et al., 2016; Algan et al., 2017; Halla et al., 2017; Guiso et al., 2017; Dustman et al., 2017; Boeri et al., 2018; Rodrik, 2018). The electoral victory of 'Leave' supporters at the Brexit Referendum of 2016 is commonly regarded as one of the first signs of the recent anti-systemic and populistic wave characterising Western politics (De Jonge, 2017). To our knowledge, our paper is the first to specifically focus on the conditions under which public investment may shape electoral preferences for this kind of political offers.

The remaining of the paper is organised as follows. Section 2 discusses institutional background, case study and data; section 3 presents the empirical setting and the models; section 4 reports the empirical results; section 5 discusses and interprets the findings; section 6 concludes.

\section{Institutional background and data}

\subsection{EU Cohesion Policy in the UK at the time of the Referendum on Brexit}

One third of the total budget of the European Union is spent within the EU Cohesion Policy. For the ongoing (2014-2020) programming period, the EU is spending on Cohesion Policy 352 billion euros, most of which is directed towards the economically 
disadvantaged territories across the continent, i.e. the regions classified as 'less developed'. Investment projects financed with these resources are intended to build new infrastructure, foster innovation, promote the development of businesses, generate employment opportunities and tackle social exclusion.

In the UK, this investment policy has been extensively financing disadvantaged territories since the early 80s. Eligibility for EU funding is assigned to so-called 'NUTS2' 2 regions before the beginning of each EU programming period, lasting seven years. During the ongoing 2014-2020 EU budget period, the UK regions classified as 'less developed'- and hence entitled to receive the highest form of EU financial support - were West Wales and the Valleys in Wales, and Cornwall and the Isles of Scilly in England (Figure 1). These two regions, the poorest of the country, are those with a regional GDP per capita below the $75 \%$ of the EU average (European Commission, 2010; 2014). Both of them have received the status of 'less developed' in the year 2000, and have been continuously financed by the EU via this funding scheme since then (Di Cataldo, 2017). Taken together, these regions account for less than $4 \%$ of the total UK population, yet they were entitled to receive around $26 \%$ of the total amount of total EU development funds allocated to the $\mathrm{UK}^{3}$ (European Commission,

\footnotetext{
${ }^{2}$ The NUTS classification (Nomenclature of Territorial Units for Statistics) is a system used to divide the EU territory. The NUTS1 level represents major socio-economic areas, the NUTS2 'intermediate' level is used for the application of EU Cohesion Policy, while the NUTS3 are smaller regions for specific diagnosis.

${ }^{3}$ In areas considered 'in highest need of financial help' by the EU and highly-financed through Cohesion Policy, EU funds represent a substantial portion of total public investment for development promotion. As an example, for the year 2014 West Wales and The Valley received around $€ 290$ million in EU funds, while the total EU expenditures in Wales (including East Wales) sum up to $€ 305$ million. The total UK Government capital expenditures for 'Economic affairs' (a spending category roughly corresponding with the main objectives of EU funds) in Wales during the same year amount to $£ 845$ million. Hence, about $30 \%$ of total capital investment in Wales have been made through Cohesion Policy, a percentage which is much higher if we only focus on West Wales and The Valley (UK Government spending data is not available for areas within Wales). Importantly, the logic through which public investment is made by the UK Government differs from the one adopted by the EU. The UK Government barely accounts for the initial level of poverty of a region. This is exemplified by the fact that expenditures for 'Economic affairs' in the richest region of the country, the London metropolitan area, is comparable to the entire amount invested in Wales ( $£ 711$ per person and
} 
2010; 2014). The remaining EU funds invested in the UK have been spread across all other regions of the country.

Figure 1.

EU funds in the UK at the time of the Referendum on Brexit

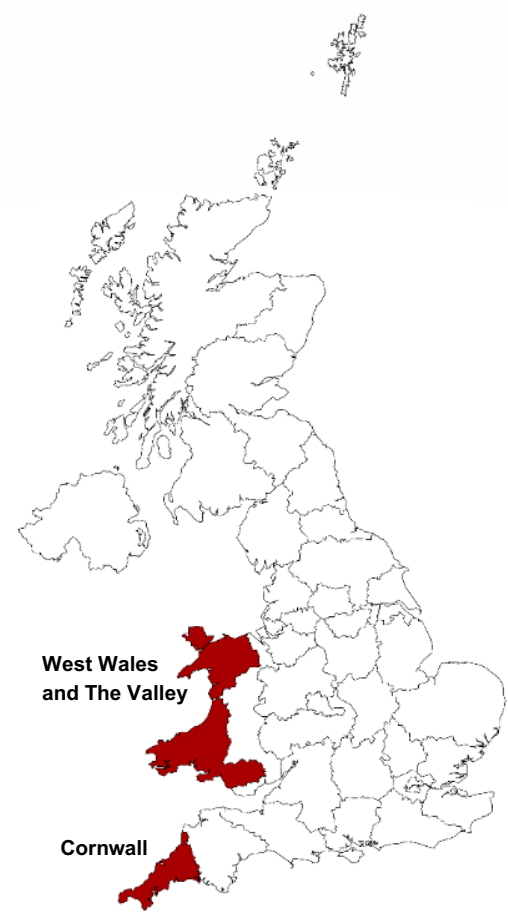

Eligibility for EU funds to 'less developed' regions (units: NUTS2 regions). Red: 'less developed regions' during 2014-2020 EU programming period.

For the 2014-2020 period, the UK is the second largest net contributor to the EU budget, after Germany. The difference between expenses towards the EU and received funds from Brussels amounts to around $€ 10$ billion (House of Commons, 2018). In light of this, it is not surprising that a recurring argument brought forward by proponents of Brexit during the Referendum campaign was that leaving the EU would save financial

£751 per person, respectively, in 2014). Hence, while in richer UK regions EU funds represent a small portion of total capital expenditures, in poorer areas the total investment for economic development would have been much lower in absence of Cohesion Policy (Data on UK Government spending retrieved from https://www.gov.uk/government/collections/publicexpenditure-statistical-analyses-pesa). 
resources to be spent on other priorities, such as financing the public healthcare system. Conversely, EU Cohesion Policy was barely mentioned during the campaign. The arguments used by Eurosceptic leaders, and the highly unequal distribution of EU funds across the country - with richer regions receiving little in per capita terms, and poorer regions receiving much more - implies that, in order to study the impact of Cohesion Policy on the Referendum's outcome, it is worth centring the attention on areas where the investment from the EU truly represents a vital portion of total public investment. Moreover, the high degree of heterogeneity across the UK implies that empirical models trying to capture the effect of EU funds on Brexit by focusing on the entire country (e.g. Becker et al., 2017) may fail to account for key idiosyncratic and unobservable characteristics of highly-funded territories.

\subsection{Wales as a case-study}

The Welsh Nation is divided into two NUTS2 regions, East Wales and West Wales and The Valley, one of which is entitled to receive the highest form of EU aid ${ }^{4}$. The geographical boundary between these two regions was set up in 1998, determining the regions' eligibility for EU funding during the 2000-2006 programming period (Gripaios and Bishop, 2006). West Wales and The Valley has been considered a 'less developed' region by the EU for the first time in 2000, and has conserved that status until today. This has entitled the region to receive large portions of EU funds, equal to around $€ 2$ billion during each of the 2000-2006, 2007-2013, and 2014-2020 periods. In comparison, East Wales has been committed by the EU around $€ 300 \mathrm{~m}$ for each of the 7-year periods.

\footnotetext{
${ }^{4}$ Unlike in other European countries, in the UK NUTS2 regions are used exclusively for EU funding purposes, having no administrative or political meaning (Gripaios and Bishop, 2006). This makes local areas belonging to neighbouring NUTS2 regions more similar, as the regional boundaries are often unrelated to any social, political or cultural characteristics.
} 
Geolocalised data on EU funds beneficiaries ${ }^{5}$ for the 2007-2013 period allow to visualise the geographical distribution of EU development projects across Wales. Figure 2 shows that a very large portion of financial resources have been received and spent in the vicinity of the border between East and West Wales, on the Western side. The concentration of projects on the South-Eastern side of the boundary, clearly visible in Figure 2, corresponds to Cardiff, Wales' capital. This city acts as 'managing authority' for all EU funds in the Welsh Nation, that is, it is responsible to receive funds from Brussels and redistribute them within Wales. While most of the beneficiary data records the location of their actual beneficiary, others are still registered with the Welsh Government Offices in Cardiff. Much of this money has likely been spent across Wales, mainly on the Western side ${ }^{6}$. However, given that we are unable to say what exact proportion of the funds officially recorded in Cardiff has been spent somewhere else, our estimates are performed both with and without Cardiff wards in the sample (cfr. Section 4.2) and our preferred specifications are the latter, i.e. excluding Cardiff.

A clear discontinuity appears visible in Figure 2 in terms of EU resources spent on the two side of the border. A large share of the EU projects implemented in West Wales appear to be concentrated in the white area of Figure 2, i.e. less than $10 \mathrm{~km}$ away from the boundary separating the region from East Wales. This is confirmed in Table A1 in the Appendix, which shows the results of regressing the proportion of EU funds per capita on a dummy variable defining whether a ward belongs West Wales, and excluding Cardiff from the sample ${ }^{7}$. The positive and significant coefficient of the West

\footnotetext{
${ }^{5}$ These data, kindly shared with us by Julia Bachtroegler, only cover approximately $60 \%$ of all total EU funds to Wales. The remaining $40 \%$ is either not recorded in the beneficiaries' dataset, or are projects with no single beneficiary and distributed across many different locations.

${ }^{6}$ Some of the funds reporting the Welsh Government in Cardiff as beneficiary has been geocoded in the area where the money has been spent by exploiting the description of the projects. As an example, one of the largest project in the data is described as the 'Dualling of the A465 between Tredegar and Brynmawr'. While this is officially recorded with the Welsh Government (Department for Economy, Science and Transport) as beneficiary, it was possible to locate the investment in West Wales, in the exact place where the A465 road is.

${ }^{7}$ Cardiff acts as 'managing authority' for all EU funds in the Welsh Nation, that is, it is responsible to receive funds from Brussels and redistribute them within Wales. While most of
} 
Wales dummy indicates that West Wales' wards near the border have received and spent comparatively more EU funds than East Wales' wards - approximately €400-500 per inhabitant more, on the basis of 2007-2013 beneficiary data.

Figure 2.

Distance in $\mathrm{km}$ from treatment border and EU funds beneficiaries in Wales

Great Britain

$$
\begin{aligned}
& \text { Beneficiaries } \\
& \begin{array}{cl}
\circ & <7 \mathrm{~m} \\
\bigcirc & 7 \mathrm{~m}-22 \mathrm{~m} \\
\bigcirc & 22 \mathrm{~m}-70 \mathrm{~m} \\
\bigcirc & 70 \mathrm{~m}-126 \mathrm{~m} \\
\bigcirc>126 m
\end{array}
\end{aligned}
$$

Distance from border $(\mathbf{k m})$

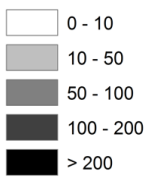

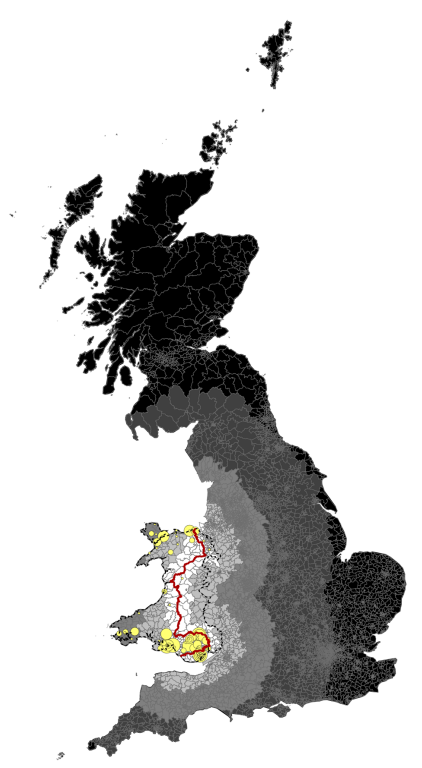

Wales

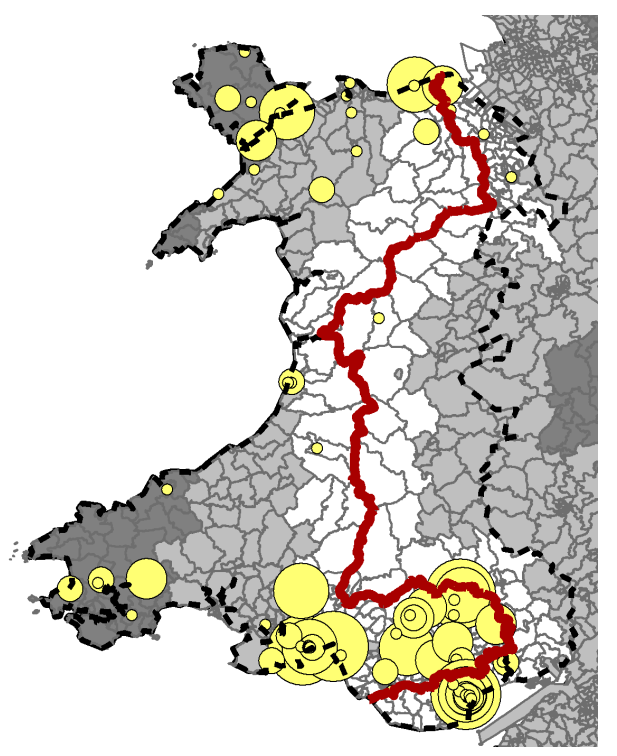

Note: the dashed line indicates the border of Wales, the red thick continuous line indicates the treatment border between East Wales and West Wales.

the beneficiary data records the location of their actual beneficiary, others are still registered with the Welsh Government Offices in Cardiff. Much of this money has likely been spent across Wales, mainly on the Western side 7 . However, given that we are unable to say what exact proportion of the funds officially recorded in Cardiff has been spent somewhere else, our estimates are performed both with and without Cardiff wards in the sample and our preferred specifications are the latter, i.e. excluding Cardiff. 


\subsection{Data}

To measure Eurosceptic votes at the 2016 UK Referendum on Brexit we rely on unique data on the Referendum results at the level of electoral wards, made available to us by the BBC. This database has been compiled by the BBC by sending individual emails to all UK Constituencies after the Referendum was held, on the basis of the UK Freedom of Information (FOI) Act, and combining together all the responses.

Our dataset is completed with information on socio-economic, labour market and demographic ward-level characteristics extracted from the UK Census (2001 and 2011). All variables on employment and industrial structure are normalised by the number of 16-74 year old residents in ward. We use these variables to test the balancing properties of our setting and to study the conditioning impact of EU funds on the Referendum results. Our analysis also exploits data on the geographical distance in $\mathrm{km}$ of each electoral ward from the border between East Wales and West Wales, calculated with the ArcGIS software. Finally, the dataset is completed with the information on EU funds beneficiaries in Wales discussed in section 2.2. Descriptive statistics for all variables used in the analysis are reported in Table A2 in the Appendix.

\section{Empirical design}

\subsection{Identification strategy and empirical models}

The fundamental identification problem of our analysis lies in the difficulty of controlling for any element correlated with European policies and potentially influencing voting preferences. A large number of unobservable local area characteristics may be confounding our estimates. To get around this issue, we exploit the geographical distribution of Cohesion Policy support in Wales to estimate the effect of Cohesion Policy on the Brexit Referendum through a regression discontinuity design (RDD) approach. The boundary separating the Welsh area highly-funded by the EU (i.e. West Wales and The Valley) and a less funded area (i.e. East Wales) is used to define treatment and control group in a quasi-experimental setting. The analysis is 
performed at the level of electoral wards. Figure 2 illustrates the wards in Britain and their distance from the treatment border.

From the seminal work of Holmes (1998), spatial regression discontinuity designs have been applied to different fields of investigation. This counterfactual method is particularly suitable to capture the effects of 'spatially-targeted' policies, as it allows to exploit geographical distance as a forcing variable that randomly defines treatment and control units (Black, 1999; Lalive, 2008; Dell, 2010; Lee and Lemieux, 2010; Gibbons et al., 2013; Koster et al., 2014; Giacomelli and Menon, 2016; Giua, 2017). The underlying idea behind the spatial RDD approach is that any characteristics must be smoothly distributed across the boundary, with the exception of the treatment itself (Black, 1999). By balancing observational units according to their distance from the boundary, the treatment (in our case: eligibility for the highest form of EU aid) is smoothly distributed across the boundary and its impact is isolated from any possible confounding factor, provided that assignment to the treatment cannot be manipulated.

Our spatial forcing variable is hence the geographical distance from the regional border. To allow for more flexibility in our estimates, the forcing variable enters in the model specifications as polynomials up to the third order. In addition, following a consolidated practice in spatial RDD studies (Holmes, 1998; Black, 1999; Jofre Monseny, 2014) our specifications are based on samples made of units in the immediate proximity of the border. In our core specifications this entails focusing on (1) all wards of Wales, or (2) all wards within $50 \mathrm{~km}$ from the treatment border, or (3) all wards within $10 \mathrm{~km}$ from the treatment border.

The baseline model is as follows:

$$
R_{w}=\beta_{0}+\beta_{1} T_{w}+\sum_{\rho=1}^{3} \gamma_{\rho}\left(f_{w}\right)^{\rho}+\left(T_{w}\right) \sum_{\rho=1}^{3} \gamma_{\rho}\left(f_{w}\right)^{\rho}+\varepsilon_{w}
$$

Where $R_{w}$ is the share of Remain votes at the 2016 Referendum on Brexit in ward $w$; $T_{w}$ is the treatment variable, a dummy equal to 1 for wards belonging to the Welsh 
region most targeted by EU Cohesion Policy (West Wales and The Valley) and 0 otherwise; $f_{w}$ is the forcing variable, the distance from the border in $\mathrm{km}$, also interacted with the treatment variable. $f_{w}$ enters either linearly or as a third order polynomial. Standard errors are clustered at the level of Local Authority ${ }^{8}$.

Besides identifying the average treatment effect (ATE) of EU regional policy on voting outcomes, our analysis aims at capturing how the effect of EU transfers on Euroscepticism varies with the changes in the living conditions of the areas targeted by the policy. In particular, we estimate the effect of EU funds on voting preferences in presence of 'labour market dynamism', proxied by the reduction of unemployment between 2001 and 2011. The heterogeneous average treatment effect (H-ATE) model is estimated with the following model:

$$
R_{w}=\beta_{0}+\beta_{1} T_{w}+\beta_{2} U_{w}+\beta_{3}\left(T_{w} \times U_{w}\right)+\sum_{\rho=1}^{3} \gamma_{\rho}\left(f_{w}\right)^{\rho}+\left(T_{w}\right) \sum_{\rho=1}^{3} \gamma_{\rho}\left(f_{w}\right)^{\rho}+\varepsilon_{w}
$$

Where $U_{w}$ represent the socio-economic and labour market dynamism of local areas, to which EU regional policy is intended to contribute. All other parameters are the same as in model (1). The H-ATE is estimated by the interaction term between the treatment dummy and the continuous $U_{w}$ variable.

\subsection{Balancing test}

The underlying assumption of a boundary RDD setting is the smooth distribution of all relevant (observable and unobservable) characteristics across the treatment border. We test the balancing properties of our empirical setting by checking for a correlation between the treatment dummy variable and a whole set of socio-economic and demographic variables extracted from the UK Census. The model is estimated for wards within $50 \mathrm{~km}$ from the treatment border, controlling for distance in $\mathrm{km}$ and

\footnotetext{
${ }^{8}$ Local Authorities (LA) are local administrative units in the UK. In Wales there are 22 LAs in total, of which 15 are in West Wales and The Valley. The territory of LAs corresponds to that of electoral Constituencies.
} 
adding polynomials of level three to assign higher weight to wards located near the border.

The results of the test are reported in Table 1. For all variables we find no evidence of a significant difference across the border. This increases our confidence that the setting we have adopted fulfils the requirement for an RDD, i.e. treatment and control groups being equal for all relevant characteristics except for the amount of available European funds. Being balanced according to the geographical distance from the boundary, we can assume that the wards belonging to the treated and untreated regions compose an 'as good as random' scenario where all characteristics are smoothly distributed among the two groups (Blundell and Costa-Dias, 2000). The wards' difference in terms of electoral preferences on Brexit will be attributed to the unique factor with a discontinuous geographical distribution, i.e. the Cohesion Policy treatment.

Table 1. Balancing test

\begin{tabular}{|c|c|c|c|c|c|c|c|c|c|}
\hline \multicolumn{10}{|c|}{ Sample: $50 \mathrm{~km}$ from border } \\
\hline Dep. var: & $\begin{array}{l}\text { Highly- } \\
\text { educated } \\
\text { (NVQ4+) } \\
(1)\end{array}$ & $\begin{array}{c}\text { Log } \\
\text { population } \\
\text { (2) }\end{array}$ & $\begin{array}{l}\text { Unempl. } \\
\text { Rate } \\
\text { (3) }\end{array}$ & $\begin{array}{l}\text { Long-term } \\
\text { unempl. } \\
\text { (4) }\end{array}$ & $\begin{array}{c}\text { Youth } \\
\text { unempl. } \\
\text { (5) }\end{array}$ & $\begin{array}{c}\text { 18-24 yo } \\
\text { population } \\
(6)\end{array}$ & $\begin{array}{c}\text { Non-British } \\
\text { population } \\
\text { (7) }\end{array}$ & $\begin{array}{c}\text { Full-time } \\
\text { students } \\
\text { (8) }\end{array}$ & $\begin{array}{c}\text { Inactive } \\
\text { population } \\
\text { (9) }\end{array}$ \\
\hline West Wales & $\begin{array}{l}-0.0442 \\
(0.0273)\end{array}$ & $\begin{array}{c}0.217 \\
(0.249)\end{array}$ & $\begin{array}{c}0.00726 \\
(0.00550)\end{array}$ & $\begin{array}{c}0.00369 \\
(0.00277)\end{array}$ & $\begin{array}{c}0.0131 \\
(0.00993)\end{array}$ & $\begin{array}{l}0.00834 \\
(0.0133)\end{array}$ & $\begin{array}{l}-0.0133 \\
(0.0155)\end{array}$ & $\begin{array}{l}0.00849 \\
(0.0211)\end{array}$ & $\begin{array}{c}0.0146 \\
(0.0160)\end{array}$ \\
\hline Observations & 1,315 & 1,315 & 1,315 & 1,315 & 1,315 & 1,315 & 1,315 & 1,315 & 1,315 \\
\hline R-squared & 0.142 & 0.216 & 0.033 & 0.037 & 0.081 & 0.047 & 0.056 & 0.115 & 0.094 \\
\hline Dep var.: & $\begin{array}{c}\text { Agricultural } \\
\text { employment } \\
\text { (10) }\end{array}$ & $\begin{array}{c}\text { Manuf. } \\
\text { employment } \\
\text { (11) }\end{array}$ & $\begin{array}{c}\text { Empl. in } \\
\text { construction } \\
\text { (12) }\end{array}$ & $\begin{array}{c}\text { Empl. in } \\
\text { mining } \\
(13)\end{array}$ & $\begin{array}{c}\text { Empl. in } \\
\text { public admin } \\
\text { (14) }\end{array}$ & $\begin{array}{c}\text { Empl. in } \\
\text { wholesale } \\
\text { and retail } \\
(15)\end{array}$ & $\begin{array}{c}\text { Empl. in } \\
\text { finance } \\
(16)\end{array}$ & $\begin{array}{l}\text { Empl. in } \\
\text { real estate } \\
(17)\end{array}$ & $\begin{array}{c}\text { Part-time } \\
\text { employment } \\
\text { (18) }\end{array}$ \\
\hline West Wales & $\begin{array}{l}-0.0121 \\
(0.0140)\end{array}$ & $\begin{array}{l}-0.00376 \\
(0.0189)\end{array}$ & $\begin{array}{c}0.00106 \\
(0.00350)\end{array}$ & $\begin{array}{l}0.000444 \\
(0.00157)\end{array}$ & $\begin{array}{c}0.00337 \\
(0.00532)\end{array}$ & $\begin{array}{l}-2.28 e-06 \\
(0.00662)\end{array}$ & $\begin{array}{l}-0.000160 \\
(0.00364)\end{array}$ & $\begin{array}{l}0.000585 \\
(0.00156)\end{array}$ & $\begin{array}{l}-0.00445 \\
(0.00628)\end{array}$ \\
\hline Observations & 1,315 & 1,315 & 1,315 & 1,315 & 1,315 & 1,315 & 1,315 & 1,315 & 1,315 \\
\hline R-squared & 0.030 & 0.135 & 0.032 & 0.040 & 0.027 & 0.177 & 0.171 & 0.104 & 0.115 \\
\hline
\end{tabular}

Notes: clustered standard errors at local authority level at local authority level in parenthesis. ${ }^{\star \star \star} p<0.01$, $\star \star p<0.05, * p<0.1$. Forcing variable: distance in $\mathrm{km}$ from border between East Wales and West Wales. West Wales: dummy variable taking value 1 for all wards belonging to West Wales and The Valley. Sample: all wards located $50 \mathrm{~km}$ or less from the treatment border, excluding wards from Cardiff. All models estimated with polynomials of order three interacted with forcing variable and treatment variable. 


\section{Results}

\section{1 ATE and H-ATE estimates}

Table 2 provides the results of equation (1), which tests the causal link between EU funds in West Wales and the Referendum result. The model is specified with the forcing variable entering linearly or as third-order polynomial and by using different RDD bandwidths based on the distance from the border between East Wales and West Wales. The sample may be composed by all wards of Wales, or by wards within $50 \mathrm{~km}$ or $10 \mathrm{~km}$ from the border on both sides. Our preferred estimates are obtained with third-order polynomials of distance, following the AIC criteria.

As shown in Table 2, in all these different specifications the coefficient of the treatment dummy is not statistically significant. We find no average treatment effect, or no evidence that Welsh wards located in the region receiving higher EU funds have voted comparatively more for either Remain or Leave, conditioning on the distance from the border. We interpret this finding as evidence that entitling citizens with more EU funds would not change their feelings towards Europe 9

The visual representation of this result is illustrated in Figure 3. The observations are linearly fitted on the two sides of the border. The Figure displays no significant jump at the treatment border, confirming that, on average, people living in areas receiving the highest-possible level of EU financial aid have not voted differently at the Brexit Referendum from citizens living in much less funded areas.

\footnotetext{
${ }^{9}$ This result reinforces the evidence obtained by Fidrmuc et al. (2019). By running a simple OLS analysis they find that EU regional development funds at NUTS2 level are not significantly associated with UK voters' decisions at the Referendum on Brexit.
} 
Table 2. Baseline RDD results - ATE model

\begin{tabular}{lcccccc}
\hline \hline Dep. var.: Share of Remain votes & & & & & \\
& Wales & $<50 \mathrm{~km}$ & $<10 \mathrm{~km}$ & Wales & $<50 \mathrm{~km}$ & $<10 \mathrm{~km}$ \\
& $(1)$ & $(2)$ & $(3)$ & $(4)$ & $(5)$ & $(6)$ \\
\hline West Wales & 0.00763 & -0.0319 & -0.00636 & -0.0127 & 0.00354 & -0.00715 \\
& $(0.0207)$ & $(0.0191)$ & $(0.0171)$ & $(0.0166)$ & $(0.0200)$ & $(0.0175)$ \\
\hline Polynomial & $1-1$ & $1-1$ & $1-1$ & $3-3$ & $3-3$ & $3-3$ \\
Observations & 823 & 1,315 & 422 & 823 & 1,315 & 422 \\
$\begin{array}{l}\text { R-squared } \\
\begin{array}{l}\text { Best polynomial degree } \\
\text { (AIC) }\end{array}\end{array}$ & 0.075 & 0.102 & 0.004 & 0.327 & 0.140 & 0.027 \\
\hline \hline
\end{tabular}

Notes: clustered standard errors at local authority level in parenthesis. ${ }^{\star *} p<0.01, * \star p<0.05,{ }^{*} p<0.1$. Forcing variable: distance in $\mathrm{km}$ from border between East Wales and West Wales. West Wales: dummy variable taking value 1 for all wards belonging to West Wales and The Valley. Samples: all wards of Wales (columns (1),(4)), all wards located $50 \mathrm{~km}$ or less from the treatment border (columns (2),(5)), all wards located $10 \mathrm{~km}$ or less from the treatment border (columns (3),(6)). Cardiff wards excluded. Models estimated with polynomials of order one (columns (1)-(3)) or order three (columns (4)-(6)) interacted with forcing variable and treatment variable.

Figure 3. ATE model - RDD plot

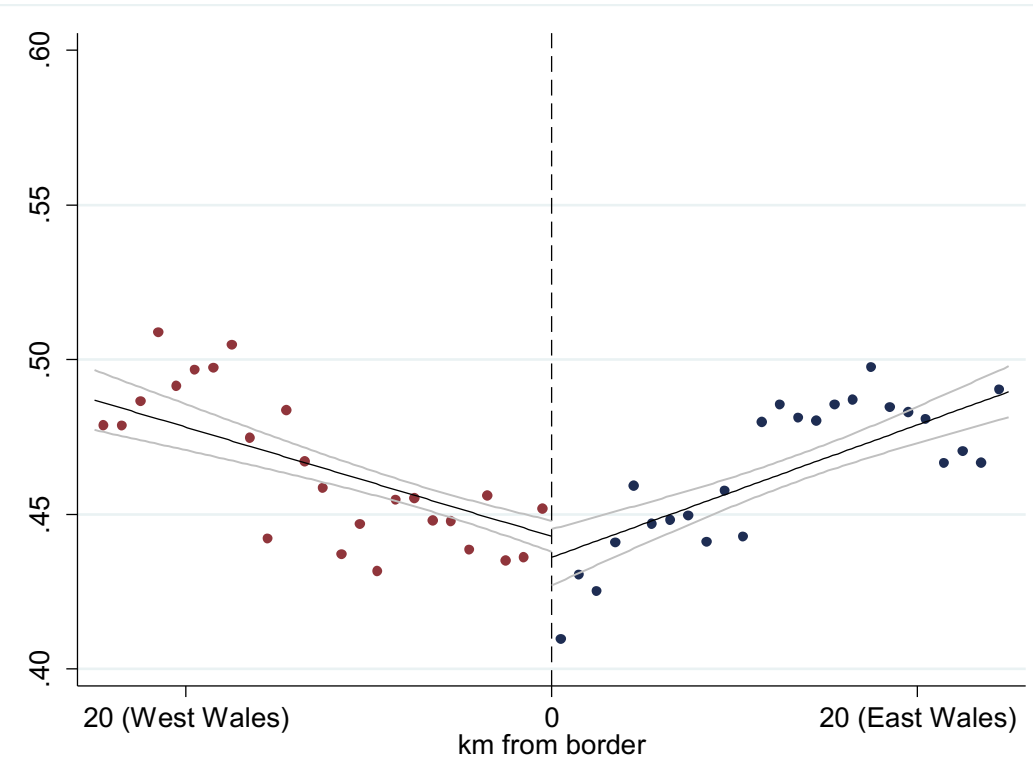

Notes: each data point represents the bin sample average for distance from treatment border, the straight line is a first-order polynomial in distance from border fitted separately on each side of the treatment boundary. Sample of Wales wards. 95\% confidence intervals are shown. 
Having established that, all in all, a higher share of EU funds alone has had no average effect on the Referendum's outcome, our next step is to examine whether EU funds can play a role if they are combined with the economic transformation of local areas. In particular, we place our attention on how the local labour market has evolved in the period preceding the vote ${ }^{10,11}$. Territories displaying a higher local labour market dynamism, where socio-economic conditions have got better while EU funds have been flowing in, may be interpreted by citizens as a success of European policies and therefore produce a stronger sense of EU belonging in them, translating into more Remain votes.

While pro-Europe positions may be fuelled by the perceived success of EU policies, the opposite can also be true. A worsening of the economic and labour performance of local areas targeted by Cohesion Policy may make these places more likely to vote against EU membership. Individuals experiencing social exclusion, job losses, or deprivation are more liable to develop feelings of discontent with 'traditional' parties. This is particularly true if socio-economic decline is spatially concentrated, as widespread disadvantage in local communities of 'left behind' places leads to the development of negative collective emotions and political discontent (Rodriguez-Pose, 2018; Altomonte et al., 2019). In areas eligible for Structural Funds, voters may assign the responsibility for declining economic trajectories and for their worse living conditions to the failure of public policies being implemented. This would induce them to vote against the EU, responsible for promoting them.

\footnotetext{
${ }^{10}$ As the main objective of EU regional policy is the promotion of 'smart, sustainable and inclusive' growth in recipient territories (European Commission, 2014), improvements in the economy and the generation of employment opportunities represent the expected outcome of policy interventions.

${ }^{11}$ In absence of GDP data at the ward level we rely on information about the unemployment rate, extracted from the Census. Wards are well-suited units to capture localised unemployment clusters. This is because most ward boundaries have been used by the UK Office for National Statistics to draw Output Areas (for which labour market and Referendum data are not available), a geographical classification of socially homogeneous areas in terms of household tenure and population size.
} 
We calculate the change in unemployment between the two latest available Censuses, i.e. 2001 and 2011. As West Wales obtained the status of 'less developed' region from the EU in 2000, this variable approximates labour market conditions in the region at the beginning of the period of high funding, before EU funds for 'less developed' regions could produce large effects. The difference between unemployment in 2001 and unemployment in 2011 captures the decrease in unemployment in ward $w$ over a 10year period preceding the Referendum.

As for model (1), model (2) is estimated using different bandwidths and with the forcing variable entering with different polynomial degrees. The results are shown in Table 3. First, it can be noted that, again, the West Wales dummy alone reports an insignificant coefficient across all specifications. The variable approximating local labour market dynamism, $\mathrm{U}$ decrease, is computed in such a way that a higher value corresponds to a higher reduction in the unemployment rate. This variable displays a significant and positive coefficient in some specifications - confirming the role of labour market dynamics as a driver of Euroscepticism - and it is insignificant otherwise. Crucially, the interaction term between the treatment dummy and the variable proxying labour improvements (U decrease) returns a positive and significant coefficient in all but one specifications. This indicates that wards within the highlyfunded West Wales where labour market conditions have most improved before the Referendum have been more prone to vote in favour of remaining in the EU. The estimated marginal effects for both West Wales and East Wales, obtained with a $10 \mathrm{~km}$ bandwidth, are displayed in Figure A1. A one percentage point reduction in unemployment in West Wales wards translates into approximately a 1.8pp increase in Remain votes, while in East Wales a similar decrease in unemployed is linked to an increase of around $0.5 \mathrm{pp}$ Remain votes, i.e. a differential of over 1 percentage point. 
Table 3. EU funds, unemployment reduction, and Brexit - H-ATE model

\begin{tabular}{lcccccc}
\hline \hline Dep. var.: Share of Remain votes & & & & & & \\
& Wales & $<50 \mathrm{~km}$ & $<10 \mathrm{~km}$ & Wales & $<50 \mathrm{~km}$ & $<10 \mathrm{~km}$ \\
& $(1)$ & $(2)$ & $(3)$ & $(4)$ & $(5)$ & $(6)$ \\
\hline West Wales & 0.0190 & -0.00556 & 0.00223 & -0.00509 & 0.00895 & 0.00114 \\
& $(0.0207)$ & $(0.0191)$ & $(0.0157)$ & $(0.0166)$ & $(0.0197)$ & $(0.0167)$ \\
U decrease & $0.430^{\star \star \star}$ & -0.588 & $0.546^{\star \star}$ & $0.416^{\star \star \star}$ & -0.566 & $0.485^{\star \star}$ \\
& $(0.132)$ & $(0.650)$ & $(0.213)$ & $(0.109)$ & $(0.636)$ & $(0.202)$ \\
West Wales x U decrease & $1.361^{\star}$ & $1.573^{\star \star}$ & $1.114^{\star}$ & 0.587 & $1.559^{\star}$ & $1.173^{\star}$ \\
& $(0.770)$ & $(0.793)$ & $(0.680)$ & $(0.453)$ & $(0.812)$ & $(0.667)$ \\
\hline Polynomial & $1-1$ & $1-1$ & $1-1$ & $3-3$ & $3-3$ & $3-3$ \\
Observations & 802 & 1,057 & 415 & 802 & 1,057 & 415 \\
R-squared & 0.181 & 0.191 & 0.139 & 0.374 & 0.209 & 0.154 \\
Best polynomial degree (AIC) & & & & $\checkmark$ & $\checkmark$ & $\checkmark$ \\
\hline \hline
\end{tabular}

Notes: clustered standard errors at local authority level in parenthesis. ${ }^{\star \star *} p<0.01,{ }^{\star *} p<0.05,{ }^{*} p<0.1$. Forcing variable: distance in $\mathrm{km}$ from border between East Wales and West Wales. West Wales: dummy variable taking value 1 for all wards belonging to West Wales and The Valley. $U$ reduction: ward-level unemployment rate difference between 2011 and 2001. Samples: all wards of Wales (columns (1),(4)), all wards located $50 \mathrm{~km}$ or less from the treatment border (columns (2),(5)), all wards located $10 \mathrm{~km}$ or less from the treatment border (columns (3),(6)). Cardiff wards excluded. Models estimated with polynomials of order one (columns (1)-(3)) or order three (columns (4)-(6)) interacted with forcing variable and treatment variable.

\subsection{Robustness checks}

The results in section 4.1 suggest that citizens living in areas eligible for the highest amount of EU Structural Funds and experiencing improvements in their local labour market have been more inclined to express a pro-Europe vote at the Referendum on Brexit. In this section, we test the robustness of this result in a number of ways.

First, our preferred samples are obtained by excluding wards of Cardiff, for the reasons explained in section 2. Table A3 in the Appendix reports the results of the $\mathrm{H}$ ATE model obtained if Cardiff wards are included in the sample. Again we find that EU funds for 'less developed regions' have had no direct impact on the Referendum, 
while financial aid from the EU is related with a higher share of Remain votes if combined with reductions in unemployment taking place in beneficiary areas.

As a second test on the H-ATE results, we modify the bandwidths used to define the treatment and control sample. More specifically, we test the results using wards located within $5 \mathrm{~km}, 15 \mathrm{~km}, 30 \mathrm{~km}$, and $40 \mathrm{~km}$ on the two sides of the treatment border. The results, shown in table A4 in the Appendix, confirm that the combination of high EU funding and improved labour conditions is significantly related to fewer Eurosceptic votes.

As a third robustness test, we adopt different proxies for labour market improvements to interact with the treatment dummy variable. We again rely on the Census and compute the variation in the long-term unemployment rate and youth unemployment rate $^{12}$ in a similar way to how the unemployment decrease variable has been created. That is, we calculate the difference between the variables' latest available value (Census 2011) and their value when West Wales obtained the status of 'less developed region' (Census 2001). While similar to the original variable on unemployment rate, these indicators capture slightly different dynamics. The long-term unemployment change reflects the capacity of the labour market to absorb more marginalised workers, often socially excluded, while the variation in youth unemployment describes the easiness for people to find their first jobs. The results of these tests are reported in Tables A5 and A6 in the Appendix. In all specifications the interaction terms have positive coefficients, most of the time statistically significant. This appears to confirm that the creation of labour opportunities for the most disadvantaged and for the youngest tends to be linked with a stronger support for EU membership in areas eligible for EU transfers.

\footnotetext{
${ }^{12}$ Following ILO definitions, long-term unemployment rate corresponds to people seeking employment for one year or longer. Youth unemployment refers to unemployment of the 1824 year old population.
} 
As a fourth test, we attempt to minimise any bias that may have been produced by spillovers driven by the possibility that wards from East Wales located next to the border have themselves being influenced by European policies. Some projects may have been implemented across the border, benefitting both regions, while some others may have attracted commuters from the Eastern side. To discard the hypothesis that the main results are driven by spillovers, we perform a new set of estimates, adopting the same sample for the treated wards, while removing all wards within $10 \mathrm{~km}$ from the Eastern side of the border (Einio and Overman, 2016). The control group is then shifted $10 \mathrm{~km}$ away from the border ${ }^{13}$. Due to this change in sample, the model is no longer estimated as a spatial RDD, i.e. assigning more weight to observations located near the border by means of controlling for distance. Given that balancing properties no longer apply to the samples, we include in the model a set of observable covariates as controls. We add all variables used for the balancing test reported in Table 2. By using this methodology we estimate both the direct impact of EU funds and the effect of Structural Funds in wards labour conditions have improved the most. The results of these estimates, illustrated in Table A7, confirm the insignificant role of EU funds for Brexit (columns (1)-(3)) if not combined with positive labour market dynamics (columns (4)-(6)).

Finally, in one additional robustness test, we replace the West Wales treatment dummy with our beneficiary variables in Table A8. While this indicator only covers a portion of all EU money spent in Wales (approximately 60\%), as shown in Table A1 the variable correlates well with the West Wales dummy. We control again for Census characteristics and test the model for all Welsh wards (columns (1), (3), Table A8) and all Welsh wards excluding Cardiff (columns (2), (4), Table A8). When testing the relationship between beneficiaries of EU funds and the Brexit Referendum once again we find no evidence that high recipients of EU resources have voted differently from

\footnotetext{
${ }^{13}$ This implies that by definition Cardiff wards are excluded from the sample, given that they are all located less than $10 \mathrm{~km}$ from the treatment border.
} 
less funded areas, and we also confirm that highly-funded wards in which unemployment has decreased more have voted Remain more.

\section{Discussion}

The evidence produced in section 4 indicates that the effect of European funds on proEurope voting outcomes only materialises under certain conditions. We find that the dynamics of the local labour market are crucial to explain the voting preferences of citizens in the areas highly subsidised by the EU. This result confirms that factual socio-economic conditions crucially shape people' perception of the European Union (Brinegar and Jolly, 2005).

Given that creating new jobs and stemming unemployment are among the main goals of EU policies, citizens may view labour improvements in their local communities as a way for EU projects to deliver. Therefore, one interpretation of our result is that people who perceive or experience personal benefits from Cohesion Policy are more prone to appreciate the policy and their promoters. This explanation would fit within the economic utilitarian theory of European integration, according to which the loyalty to the idea of Europe depends on the perceived benefits further integration can provide (Gabel and Palmer, 1995; Gabel et al., 1997).

While we cannot directly measure the extent to which the observed reduction in unemployment (a proxy for local economic dynamism) is directly due to EU policies, our findings entail that if EU projects are capable of producing strong effects on the local labour market - by e.g. fostering employment for the socially excluded and young people - this would translate into a lower level of Euroscepticism.

The impact of EU subsidies on European attitudes, conditional on the effectiveness of EU policies, can be indirectly examined by looking at key elements facilitating the profitable use of Structural Funds. One factor increasing the local capacity to absorb EU transfer and obtain higher economic returns from them is the presence of highlyeducated individuals (Becker et al., 2013). The endowment of skilled workers enables 
technology adoption (Benhabib and Spiegel, 1994) and the efficient management of EU resources (Becker et al., 2013). Therefore, we can use a proxy for the level of human capital in wards to check whether and how this variable relates to EU funds and Euroscepticism.

We approximate the human capital stock in wards with the share of tertiary educated individuals, relying on 2011 Census data. First, we use this variable to test whether it mediates the effect of EU funds on Brexit as in the case of labour market dynamism, estimating a new version of the H-ATE RDD model. The results, shown in Table A9, demonstrate that, although a higher proportion of skilled workers directly connects with more Remain votes, human capital does not play a conditional effect on the link between EU funds and Brexit.

However, our main interest is to verify whether the effect uncovered in section 4 (i.e. the generation of new employment opportunities makes EU funds positively correlate with a pro-Europe attitude) is stronger in places endowed with highly-educated people. We do so by re-estimating the H-ATE model with unemployment reduction as conditioning variable, similar to what we do in section 4 , by splitting the sample on the basis of higher/lower than average human capital. The results of Table A10 indicate that the role of labour market dynamism as mediator of the EU funds' effect on Brexit is much stronger in areas endowed with higher human capital.

Hence, the combination of lower unemployment and higher stock of human capital are the two factors determining a larger effect of European funds on public support for the EU. In this scheme, human capital may be capturing local areas' capacity to absorb EU transfers and make good use of them, as discussed above. Another interpretation is that it reflects the awareness of beneficiary wards over the existence of the policy. Previous evidence reported a strong association between the proportion of highly-educated people and the awareness of Cohesion Policy (Osterloh, 2011; Capello and Perucca, 2017). This entails that, among the regions financed by the EU through Cohesion Policy, those in which EU investment efforts are known more are those 
where human capital is higher. If we follow this interpretation and apply it to our setting, the differential conditioning impact of unemployment decrease depending on the level of human capital, as shown in Table A10, is due to the fact that those being aware that West Wales is a region receiving financial aid from the EU are more likely to relate any improvements in the labour market to the effect of EU policies.

\section{Conclusions}

This paper has investigated the extent to which Eurosceptic voting preferences can be influenced by EU policies. It leverages the case of the EU structural funds, the key EU policy tool targeting the economic challenges that have been linked to the world-wide raise of anti-system electoral preferences. The study exploits a quasi-experimental setting in the UK context, where some territories were classified as 'in highest need' of socio-economic support by the EU - and hence entitled to receive the highest form of EU funding - when the Referendum on Brexit was held. The paper investigates whether this 'special' treatment in terms of EU financial support has influenced the vote at the Referendum in beneficiary areas. The boundary between West Wales and its neighbouring region - that defines eligibility for EU financial aids - is used to identify 'treated' and 'control' units and uncover whether and under what conditions EU funding may influence electoral support for EU integration.

Regression discontinuity estimates suggest that, all else equal, wards targeted by the highest proportion of EU funds have not behaved differently from less subsidised areas when it comes to supporting EU membership in the ballot box. Conversely, voters are more prone to support EU Membership if EU funding is coupled with tangible improvements in local labour markets. A significant decrease in the level of unemployment is robustly linked with fewer Eurosceptic votes in areas highly-funded by the European Union, vis-à-vis less well-funded territories.

This result, robust to a full battery of robustness tests, offers (for the first time) causal evidence that being in receipt of EU funds does not 'automatically' make local citizens 
more supportive of the European Union. Only where EU investments are combined with the generation of new employment opportunities and a positive socio-economic transformation of local territories - an explicit target of EU development policies citizens are more likely to electorally support the EU as the promoter of positive change in their surrounding economic environment. Further empirical tests seem to suggest that labour market dynamism in beneficiary areas is more likely to lower Eurosceptic votes if citizens are more aware of EU interventions, therefore more directly linking positive change with EU interventions.

These findings are in line with a growing body of evidence on economic dynamics as the fundamental driver of anti-establishment and Eurosceptic voting choices (Rodrik, 2018; Colantone and Stanig, 2018; Rodriguez-Pose, 2018; Guiso et al., 2018; Dijkstra et al., 2019). Our findings confirm that support for the process of European integration is strongly influenced by economic factors, with special reference to labour market opportunities. What our original results add to the existing discourse is the role of active public policies in shaping electoral behaviour. Discomfort and resentment of EU citizens can indeed be mitigated and channelled towards constructive and internationally cooperative political options. However, what seems to matter for citizens is not the financial aid targeting less developed regions, but rather the capability of these funds to concretely mitigate the lack of economic opportunities.

Areas most heavily funded by the EU tend to develop a more favourable view of Europe if (and only if) citizens observe visible socio-economic improvements in their local communities with potential personal benefits from EU intervention. In this perspective, future support for the process of European integration is highly dependent on the capacity of all EU policies to deliver concrete benefits to be felt at the local level. Impactful policies are therefore a fundamental tool to buy-in citizens from less developed regions into the EU project. Money cannot buy love (for the EU), but impact and positive transformation certainly can. 


\section{References}

Alabrese, E., Becker, S. O., Fetzer, T., and Novy, D. (2019). Who voted for Brexit? Individual and regional data combined. European Journal of Political Economy, 56, 132-150.

Albanese, G, Barone G, de Blasio G, (2019) Populist Voting and Losers' Discontent: Does Redistribution Matter?, Marco Fanno Working Paper, no. 239, September 2019.

Altomonte C, Gennaro G, Passarelli F (2019), Collective Emotions and Protest Vote, CESIFO Working Papers no. 7463.

Algan Y, Guriev S, Papaioannou E, Passari E (2017), The European Trust Crisis and the Rise of Populism, CEPR Discussion Papers no. 12444.

Autor DH, Dorn D, Hanson GH, Majlesi K (2016), Importing Political Polarization? The Electoral Consequences of Rising Trade Exposure, NBER Working Papers no. 22637.

Barone G, D'Ignazio A, de Blasio G, Naticchioni P (2016), Mr. Rossi, Mr. Hu and politics. The role of immigration in shaping natives' voting behavior, Journal of Public Economics, vol. 136(C): 1-13.

Bachtler, J. and C. Mendez (2017). 'European Identity and Citizen Attitudes to Cohesion Policy: What do we know?' COHESIFY RESEARCH PAPER 1.

Becker, S. O., Egger, P. H., and von Ehrlich, M. (2010). Going NUTS: The effect of EU structural funds on regional performance. Journal of Public Economics, 94(9-10), 578-590.

Becker, S. O., Egger, P. H., and von Ehrlich, M. (2013). Absorptive capacity and the growth and investment effects of regional transfers: Regression discontinuity design with heterogeneous treatment effects. American Economic Journal: Economic Policy, 5(4), 29-77.

Becker S, Egger PH, von Ehrlich M (2018), Effects of EU Regional Policy: 1989-2013, Regional Science and Urban Economics, 69: 143-152.

Becker SO, Fetzer T, Novy D (2017), Who voted for Brexit? A comprehensive districtlevel analysis, Economic Policy, 32, 601-650.

Begg, I. (2008): "Subsidiarity in Regional Policy," in Subsidiarity and Economic Reform in Europe, ed. by G. Gelauff, I. Grilo, and A. Lejour, pp. 291-310. Springer.

Black, S. (1999), “Do Better Schools Matter? Parental Valuation of Elementary Education", Quarterly Journal of Economics 114, 577-599. 
Blundell, Richard and Monica Costa-Dias. 2009. "Alternative Approaches to Evaluation in Empirical Microeconomics," Journal of Human Resources, 44(3), 565640.

Boeri T, Mishra P, Papageorgiou C, Spilimbergo A (2018), Populism and Civil Society, CEPR Discussion Paper no. 13306.

Borin A, Macchi E, Mancini M (2018), EU Transfers and Euroscepticism: Can't Buy Me Love?, mimeo.

Brinegar, A.P. and Jolly, S.K. (2005) Location, location, location: National contextual factors and public support for European integration. European Union Politics, 6: 155-180.

Clarke, S. and M. Whittaker (2016), The Importance of Place: explaining the characteristics underpinning the Brexit vote across different parts of the UK. Resolution Foundation.

Capello, R. and Perucca, G. (2017) 'Understanding citizen perception of European Union Cohesion Policy: the role of the local context' Regional Studies, forthcoming.

Crescenzi, R., Di Cataldo, M., Faggian, A. (2018). 'Internationalised at work and localistic at home: the 'split' Europeanisation behind Brexit' Papers in Regional Science 97, 117-132.

Colantone I, Stanig P (2018), Global Competition and Brexit, American Political Science Review, 112(2): 201-218.

De Jonge, L. (2017). 'First Brexit and now Trump: what is populism and how might we view it?' University of Cambridge blog, January 2017.

Dellmuth, L. and Chalmers, A. (2018) 'All spending is not equal: European Union public spending, policy feedback and citizens' support for the EU', European Journal of Political Resarch.

Di Cataldo, M. (2017). The impact of EU Objective 1 funds on regional development: Evidence from the U.K. and the prospect of Brexit. Journal of Regional Science, 57 (5): 814-839.

Di Cataldo, M. and V. Monastiriotis (2019). Regional needs, regional targeting and regional growth: an assessment of the impact of EU funds in UK regions. Regional Studies, forthcoming.

Dijkstra, L., Poelman, H., Rodríguez-Pose, A. (2019). The geography of EU discontent. Regional Studies, forthcoming. 
Einio, Elias and H. G. Overman (2016). The (displacement) effects of spatially targeted enterprise initiatives: Evidence from UK LEGI", CEPR Discussion paper, DP 11112.

Fidrmuc, J., Hulényib, M. and Tunalıc, C. B. (2019), Can money buy EU love?, European Journal of Political Economy, forthcoming

Gabel, Matthew and Harvey Palmer (1995). Understanding Variation in Public Support of European Integration. European Journal of Political Research. 27: 3-19.

Gabel, Matthew and Guy D. Whitten (1997). Economic Conditions, Economic Perceptions, and Public Support for European Integration. Political Behavior. 19: 81-96.

Gibbons, S., Machin, S., and Silva, O. (2013). Valuing school quality using boundary discontinuities. Journal of Urban Economics, 75, 15-28.

Giacomelli, S., \& Menon, C. (2016). Does weak contract enforcement affect firm size? Evidence from the neighbour's court. Journal of Economic Geography, 17(6), 12511282.

Giua, M. (2017). Spatial discontinuity for the impact assessment of the EU regional policy: The case of Italian objective 1 regions. Journal of Regional Science, 57(1), 109131.

Guiso L, Herrera H, Morelli M, Sonno T (2017), Demand and Supply of Populism, CEPR Discussion Paper no. 11871.

Halla A, Wagner F, Zweimuller J (2017), Immigration and voting for the far right, Journal of the European Economic Association, 15(6):1341-1385.

Harris, R., and Charlton, M. (2017). Voting out of the European Union: Exploring the geography of Leave. Environment and Planning A, forthcoming.

Holmes, T. (1998), "The Effects of State Policies on the Location of Industry: Evidence from State Borders", Journal of Political Economy 106, 667-705.

Hobolt, S. and Wratil, C. (2016). 'Which argument will win the referendum immigration, or the economy?' EUROPP European Politics and Policy Blog, London School of Economics.

Christopher Huggins (2018) Did EU regional spending affect the Brexit referendum?, Regional Studies, Regional Science, 5:1, 388-396

Imbens G, Lemieux T (2008), Regression discontinuity designs: A guide to practice, Journal of Econometrics, 142(2): 615-635.

Jofre-Monseny, J. (2014). 'The effects of unemployment protection on migration in lagging regions', Journal of Urban Economics 83, 73-86. 
Koster, H. R., van Ommeren, J. N., \& Rietveld, P. (2014). Historic amenities, income and sorting of households. Journal of Economic Geography, 16(1), 203-236.

Lee S, Lemieux T (2010), Regression Discontinuity Designs in Economics, Journal of Economic Literature, 48(2): 281-355.

López-Bazo, E. and Royuela, V. (2017). 'PERCEIVE deliverable 2.2: Mapping the determinants of EU citizen's perception and identification'. DOI 10.6092/unibo/amsacta/5765

Los, B., McCann, P., Springford, J., and Thissen, M. (2017). The mismatch between local voting and the local economic consequences of Brexit. Regional Studies, 51(5), 786799.

Osterloh, S. (2011). 'Can regional transfers buy public support? Evidence from EU structural policy' ZEW Discussion Papers, No. 11-011.

Rodríguez-Pose A (2018), The revenge of the places that don't matter (and what to do about it), Cambridge Journal of Regions, Economy and Society, 11(1): 189-209.

Rodrik D (2017), 'Populism and the Economics of Globalization', NBER Working Paper no. 23559.

Scruton, R. (2016). 'Who are we?', Prospect magazine, retrieved from: www.prospectmagazine.co.uk/magazine/who-are-we. 


\section{Appendix}

Table A1. EU funds per inhabitant in West Wales (beneficiary data)

\begin{tabular}{lccc}
\hline \hline Dep. var.: EU funds per inhabitant & & & \\
& Wales & $<50 \mathrm{~km}$ & $<10 \mathrm{~km}$ \\
& $(1)$ & $(2)$ & $(3)$ \\
\hline \multirow{2}{*}{ West Wales } & $542.0^{\star \star \star}$ & $550.0^{\star \star \star}$ & $372.2^{\star \star}$ \\
& $(103.7)$ & $(122.1)$ & $(159.0)$ \\
\hline Observations & 823 & 1,315 & 422 \\
R-squared & 0.007 & 0.013 & 0.007 \\
\hline \hline
\end{tabular}

Notes: clustered standard errors at local authority level in parenthesis. $* \star \star x<0.01, * \star p<0.05,{ }^{*} p<0.1$. EU funds per inhabitant as dependent variable, calculated on the basis of available beneficiary data. West Wales: dummy variable taking value 1 for all wards belonging to West Wales and The Valley. Cardiff wards excluded. 
Table A2. Descriptive statistics

\begin{tabular}{|c|c|c|c|c|c|c|c|c|c|}
\hline \multirow[b]{3}{*}{ Variable } & \multicolumn{9}{|c|}{ Cardiff wards excluded } \\
\hline & \multicolumn{3}{|c|}{ Wales } & \multicolumn{3}{|l|}{$<50 \mathrm{~km}$} & \multicolumn{3}{|c|}{$<10 \mathrm{~km}$} \\
\hline & Obs & Mean & Std. Dev. & Obs & Mean & Std. Dev. & Obs & Mean & Std. Dev. \\
\hline $\begin{array}{l}\text { Share of Remain } \\
\text { votes }^{\mathrm{a}}\end{array}$ & 823 & 0.47 & 0.05 & 1,315 & 0.47 & 0.06 & 422 & 0.447 & 0.037 \\
\hline West Wales & 824 & 0.681 & 0.466 & 1,315 & 0.354 & 0.479 & 422 & 0.590 & 0.492 \\
\hline $\begin{array}{l}€ \text { of EU funds } \\
\text { (beneficiaries) }^{a}\end{array}$ & 823 & 398.2 & 3047 & 1,315 & 219.0 & 2344 & 422 & 387.2 & 5052 \\
\hline $\begin{array}{l}\text { Unemployment } \\
\text { decrease }^{\text {b }}\end{array}$ & 803 & -0.006 & 0.012 & 1,057 & -0.008 & 0.012 & 415 & -0.009 & 0.010 \\
\hline $\begin{array}{l}\text { Long-term } \\
\text { unemployment } \\
\text { decrease }^{b}\end{array}$ & 803 & -0.005 & 0.007 & 1,057 & -0.006 & 0.007 & 415 & -0.007 & 0.006 \\
\hline $\begin{array}{l}\text { Youth } \\
\text { unemployment } \\
\text { decrease }^{b}\end{array}$ & 803 & -0.015 & 0.030 & 1,057 & -0.016 & 0.027 & 415 & -0.019 & 0.028 \\
\hline Log population & 824 & 7.920 & 0.557 & 1,315 & 8.293 & 0.693 & 422 & 8.032 & 0.570 \\
\hline Highly-educated (NVQ4+) ${ }^{a}$ & 824 & 0.244 & 0.084 & 1,315 & 0.257 & 0.092 & 422 & 0.239 & 0.087 \\
\hline Unemployment & 824 & 0.041 & 0.020 & 1,315 & 0.041 & 0.020 & 422 & 0.042 & 0.017 \\
\hline $\begin{array}{l}\text { Long-term } \\
\text { unemployment }\end{array}$ & 824 & 0.016 & 0.009 & 1,315 & 0.016 & 0.009 & 422 & 0.017 & 0.008 \\
\hline $\begin{array}{l}\text { Youth } \\
\text { unemployment }\end{array}$ & 824 & 0.085 & 0.037 & 1,315 & 0.079 & 0.036 & 422 & 0.090 & 0.035 \\
\hline $\begin{array}{l}18-24 \text { yo } \\
\text { population }^{\mathrm{a}}\end{array}$ & 824 & 0.139 & 0.067 & 1,315 & 0.141 & 0.070 & 422 & 0.135 & 0.042 \\
\hline $\begin{array}{l}\text { Non-British } \\
\text { population }^{\mathrm{a}}\end{array}$ & 824 & 0.046 & 0.042 & 1,315 & 0.057 & 0.058 & 422 & 0.043 & 0.045 \\
\hline Full-time students ${ }^{a}$ & 824 & 0.020 & 0.020 & 1,315 & 0.022 & 0.020 & 422 & 0.019 & 0.012 \\
\hline $\begin{array}{l}\text { Inactive } \\
\text { population }^{\text {a }}\end{array}$ & 824 & 0.350 & 0.082 & 1,315 & 0.345 & 0.080 & 422 & 0.341 & 0.054 \\
\hline $\begin{array}{l}\text { Agricultural } \\
\text { employment }^{\mathrm{b}}\end{array}$ & 824 & 0.020 & 0.031 & 1,315 & 0.017 & 0.029 & 422 & 0.015 & 0.029 \\
\hline $\begin{array}{l}\text { Manufacturing } \\
\text { employment }^{\mathrm{b}}\end{array}$ & 824 & 0.067 & 0.033 & 1,315 & 0.072 & 0.033 & 422 & 0.078 & 0.031 \\
\hline $\begin{array}{l}\text { Employment in } \\
\text { construction }^{\mathrm{b}}\end{array}$ & 824 & 0.055 & 0.014 & 1,315 & 0.055 & 0.017 & 422 & 0.053 & 0.011 \\
\hline $\begin{array}{l}\text { Employment in } \\
\text { mining }^{\mathrm{b}}\end{array}$ & 824 & 0.002 & 0.003 & 1,315 & 0.002 & 0.002 & 422 & 0.002 & 0.003 \\
\hline $\begin{array}{l}\text { Employment in } \\
\text { public admin }{ }^{\mathrm{b}}\end{array}$ & 824 & 0.047 & 0.021 & 1,315 & 0.046 & 0.020 & 422 & 0.047 & 0.019 \\
\hline $\begin{array}{l}\text { Employment in } \\
\text { wholesale and } \\
\text { retail }^{\mathrm{b}}\end{array}$ & 824 & 0.096 & 0.024 & 1,315 & 0.106 & 0.030 & 422 & 0.091 & 0.017 \\
\hline $\begin{array}{l}\text { Employment in } \\
\text { finance }^{b}\end{array}$ & 824 & 0.015 & 0.009 & 1,315 & 0.021 & 0.014 & 422 & 0.017 & 0.009 \\
\hline $\begin{array}{l}\text { Employment in } \\
\text { real estate }^{\mathrm{b}}\end{array}$ & 824 & 0.008 & 0.003 & 1,315 & 0.009 & 0.004 & 422 & 0.008 & 0.003 \\
\hline $\begin{array}{l}\text { Part-time } \\
\text { employment }^{\text {b }}\end{array}$ & 824 & 0.146 & 0.029 & 1,315 & 0.154 & 0.036 & 422 & 0.140 & 0.017 \\
\hline
\end{tabular}

a: calculated as share of ward residents; b: calculated as share of 16-74 year old residents. 
EU funds, local opportunities, and the Brexit vote

Figure A1. H-ATE - estimated marginal effects

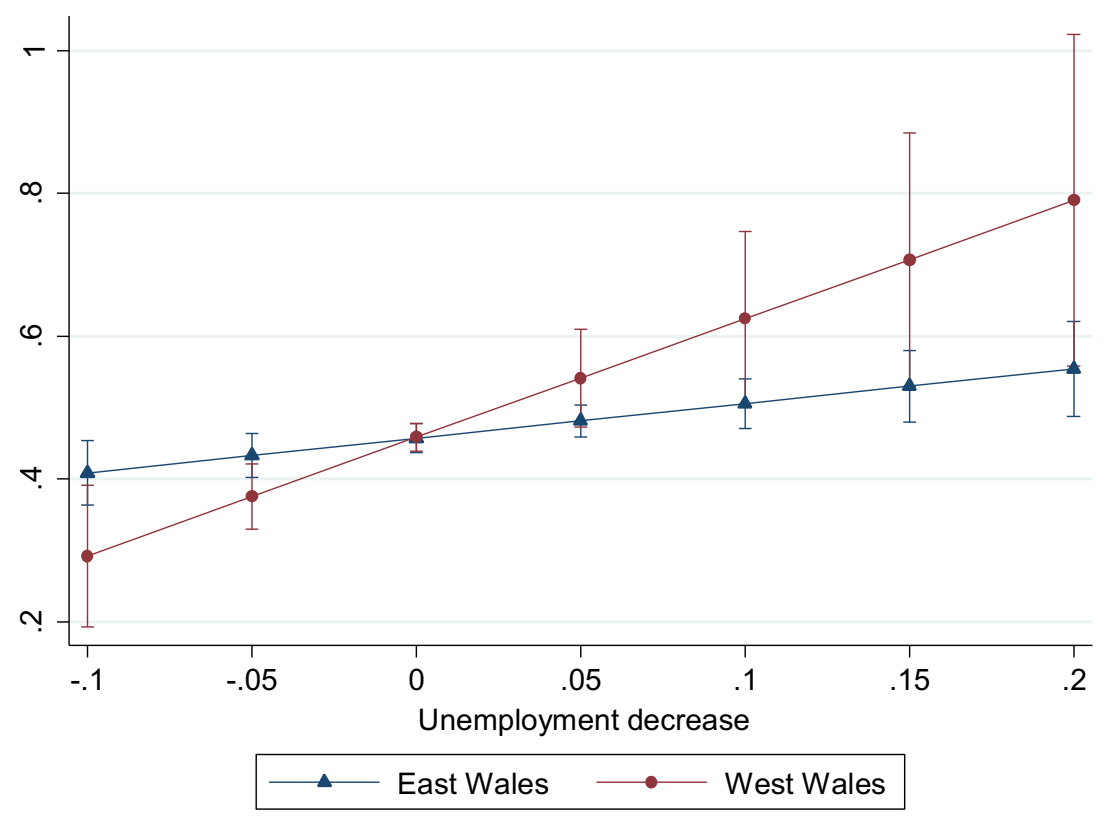


Table A3. EU funds, unemployment reduction, and Brexit (Cardiff wards included)

\begin{tabular}{|c|c|c|c|c|c|c|}
\hline \multicolumn{7}{|c|}{ Dep. var.: Share of Remain votes } \\
\hline & Wales & $<50 \mathrm{~km}$ & $<10 \mathrm{~km}$ & Wales & $<50 \mathrm{~km}$ & $<10 \mathrm{~km}$ \\
\hline & (1) & (2) & (3) & $(4)$ & (5) & $(6)$ \\
\hline \multirow[t]{2}{*}{ West Wales } & -0.00051 & -0.0220 & -0.0173 & -0.0264 & -0.0174 & -0.0112 \\
\hline & $(0.0275)$ & $(0.0243)$ & $(0.0237)$ & $(0.0257)$ & $(0.0298)$ & $(0.0208)$ \\
\hline \multirow[t]{2}{*}{ U decrease } & -0.377 & -0.814 & -0.671 & -0.397 & -0.819 & -0.596 \\
\hline & $(0.720)$ & $(0.611)$ & $(1.043)$ & $(0.715)$ & $(0.621)$ & $(0.893)$ \\
\hline \multirow{2}{*}{$\begin{array}{l}\text { West Wales } \times U \\
\text { decrease }\end{array}$} & $1.912^{\star}$ & $1.799 \star \star$ & $2.331^{\star}$ & $1.399 *$ & $1.812^{\star \star}$ & $2.255^{\star \star}$ \\
\hline & $(1.045)$ & $(0.761)$ & $(1.226)$ & $(0.840)$ & $(0.800)$ & $(1.096)$ \\
\hline Polynomial & $1-1$ & $1-1$ & $1-1$ & $3-3$ & 3-3 & 3-3 \\
\hline Observations & 831 & 1,086 & 444 & 831 & 1,086 & 444 \\
\hline R-squared & 0.129 & 0.165 & 0.131 & 0.282 & 0.178 & 0.147 \\
\hline $\begin{array}{l}\text { Best polynomial } \\
\text { degree (AIC) }\end{array}$ & & & & $\checkmark$ & $\checkmark$ & $\checkmark$ \\
\hline
\end{tabular}

Notes: clustered standard errors at local authority level in parenthesis. $* \star * p<0.01, * * p<0.05,{ }^{*} p<0.1$. Forcing variable: distance in $\mathrm{km}$ from border between East Wales and West Wales. West Wales: dummy variable taking value 1 for all wards belonging to West Wales and The Valley. $U$ reduction: ward-level unemployment rate difference between 2011 and 2001. Samples: all wards of Wales (columns (1),(4)), all wards located $50 \mathrm{~km}$ or less from the treatment border (columns (2),(5)), all wards located $10 \mathrm{~km}$ or less from the treatment border (columns (3),(6)). Cardiff wards excluded. Models estimated with polynomials of order one (columns (1)-(3)) or order three (columns (4)-(6)) interacted with forcing variable and treatment variable. 
Table A4. EU funds, unemployment reduction, and Brexit (varying bandwidths)

\begin{tabular}{lcccc}
\hline \hline Dep. var.: Share of Remain votes & & & & \\
& $<5 \mathrm{~km}$ & $<15 \mathrm{~km}$ & $<30 \mathrm{~km}$ & $<40 \mathrm{~km}$ \\
& $(1)$ & $(2)$ & $(3)$ & $(4)$ \\
\hline West Wales & 0.00192 & -0.00249 & 0.00773 & 0.00453 \\
& $(0.0161)$ & $(0.0163)$ & $(0.0176)$ & $(0.0179)$ \\
U decrease & 0.343 & $0.559 * \star *$ & -0.381 & -0.859 \\
& $(0.392)$ & $(0.184)$ & $(0.430)$ & $(0.549)$ \\
West Wales x U decrease & $1.499 *$ & $1.066 *$ & $1.389 * \star$ & $1.869 * \star$ \\
& $(0.811)$ & $(0.629)$ & $(0.663)$ & $(0.769)$ \\
\hline Polynomial & $3-3$ & $3-3$ & $3-3$ & $3-3$ \\
Observations & 261 & 517 & 740 & 897 \\
R-squared & 0.235 & 0.183 & 0.184 & 0.150 \\
Best polynomial degree (AIC) & $\checkmark$ & $\checkmark$ & $\checkmark$ & $\checkmark$ \\
\hline \hline
\end{tabular}

Notes: clustered standard errors at local authority level in parenthesis. ${ }^{\star *} p<0.01,{ }^{\star *} p<0.05,{ }^{*} p<0.1$. Forcing variable: distance in $\mathrm{km}$ from border between East Wales and West Wales. West Wales: dummy variable taking value 1 for all wards belonging to West Wales and The Valley. $U$ reduction: ward-level unemployment rate difference between 2011 and 2001. Samples: all wards located $5 \mathrm{~km}$ or less from the treatment border (column (1)), all wards located $15 \mathrm{~km}$ or less from the treatment border (column (2)), all wards located $30 \mathrm{~km}$ or less from the treatment border (column (3)), all wards located $40 \mathrm{~km}$ or less from the treatment border (column (4)). Cardiff wards excluded. Models estimated with polynomials of order three interacted with forcing variable and treatment variable. 
Table A5. EU funds, long-term unemployment reduction, and Brexit

\begin{tabular}{lcccccc}
\hline \hline Dep. var.: Share of Remain votes & & & & & & \\
& Wales & $<50 \mathrm{~km}$ & $<10 \mathrm{~km}$ & Wales & $<50 \mathrm{~km}$ & $<10 \mathrm{~km}$ \\
& $(1)$ & $(2)$ & $(3)$ & $(4)$ & $(5)$ & $(6)$ \\
\hline West Wales & 0.0244 & -0.00056 & 0.000501 & -0.00041 & 0.0134 & -0.00058 \\
& $(0.0211)$ & $(0.0188)$ & $(0.0165)$ & $(0.0163)$ & $(0.0188)$ & $(0.0175)$ \\
& $1.172^{\star \star}$ & -0.367 & $1.682^{\star \star \star}$ & $1.134^{\star \star}$ & -0.294 & $1.640^{\star \star \star}$ \\
LTU decrease & $(0.521)$ & $(1.078)$ & $(0.563)$ & $(0.430)$ & $(1.080)$ & $(0.565)$ \\
& $2.201^{\star}$ & $2.552^{\star \star}$ & 0.818 & 1.211 & $2.454^{\star}$ & 0.812 \\
West Wales x LTU decrease & $(1.300)$ & $(1.262)$ & $(1.201)$ & $(0.814)$ & $(1.312)$ & $(1.195)$ \\
\hline Polynomial & $1-1$ & $1-1$ & $1-1$ & $3-3$ & $3-3$ & $3-3$ \\
Observations & 802 & 1,057 & 415 & 802 & 1,057 & 415 \\
R-squared & 0.220 & 0.192 & 0.152 & 0.398 & 0.209 & 0.161 \\
Best polynomial degree (AIC) & & & & $\checkmark$ & $\checkmark$ & $\checkmark$ \\
\hline \hline
\end{tabular}

Notes: clustered standard errors at local authority level in parenthesis. $* \star * p<0.01, * \star p<0.05, * p<0.1$. Forcing variable: distance in $\mathrm{km}$ from border between East Wales and West Wales. West Wales: dummy variable taking value 1 for all wards belonging to West Wales and The Valley. LTU decrease: ward-level long-term unemployment rate difference between 2011 and 2001. Samples: all wards of Wales (columns (1),(4)), all wards located $50 \mathrm{~km}$ or less from the treatment border (columns (2),(5)), all wards located 10 $\mathrm{km}$ or less from the treatment border (columns (3),(6)). Cardiff wards excluded. Models estimated with polynomials of order one (columns (1)-(3)) or order three (columns (4)-(6)) interacted with forcing variable and treatment variable. 
Table A6. EU funds, youth unemployment reduction, and Brexit

\begin{tabular}{lcccccc}
\hline \hline Dep. var.: Share of Remain votes & & & & & & \\
& Wales & $<50 \mathrm{~km}$ & $<10 \mathrm{~km}$ & Wales & $<50 \mathrm{~km}$ & $<10 \mathrm{~km}$ \\
& $(1)$ & $(2)$ & $(3)$ & $(4)$ & $(5)$ & $(6)$ \\
\hline West Wales & 0.0154 & -0.0148 & -0.00174 & -0.00735 & 0.00315 & -0.00167 \\
& $(0.0223)$ & $(0.0189)$ & $(0.0169)$ & $(0.0174)$ & $(0.0191)$ & $(0.0178)$ \\
Youth U decrease & 0.164 & 0.188 & 0.0460 & 0.306 & 0.172 & -0.0366 \\
& $(0.602)$ & $(1.287)$ & $(0.535)$ & $(0.473)$ & $(1.208)$ & $(0.483)$ \\
West Wales x Youth U & $2.214^{\star}$ & 1.320 & $1.818^{\star}$ & $1.279^{\star}$ & 1.384 & $1.922^{\star}$ \\
decrease & $(1.115)$ & $(1.417)$ & $(1.060)$ & $(0.733)$ & $(1.385)$ & $(1.007)$ \\
\hline Polynomial & $1-1$ & $1-1$ & $1-1$ & $3-3$ & $3-3$ & $3-3$ \\
Observations & 802 & 1,057 & 415 & 802 & 1,057 & 415 \\
R-squared & 0.120 & 0.170 & 0.040 & 0.351 & 0.190 & 0.060 \\
Best polynomial degree (AIC) & & & & $\checkmark$ & $\checkmark$ & $\checkmark$ \\
\hline \hline
\end{tabular}

Notes: clustered standard errors at local authority level in parenthesis. ${ }^{\star *} p<0.01, * \star p<0.05,{ }^{*} p<0.1$. Forcing variable: distance in $\mathrm{km}$ from border between East Wales and West Wales. West Wales: dummy variable taking value 1 for all wards belonging to West Wales and The Valley. Youth U reduction: wardlevel 16-24 yo unemployment rate difference between 2011 and 2001. Samples: all wards of Wales (columns (1),(4)), all wards located $50 \mathrm{~km}$ or less from the treatment border (columns (2),(5)), all wards located $10 \mathrm{~km}$ or less from the treatment border (columns (3),(6)). Cardiff wards excluded. Models estimated with polynomials of order one (columns (1)-(3)) or order three (columns (4)-(6)) interacted with forcing variable and treatment variable. 
Table A7. Test for spillover effects

Dep. var.: Share of Remain votes

\begin{tabular}{|c|c|c|c|c|c|}
\hline & $\begin{array}{c}<50 \mathrm{~km} \\
\text { (West Wales) }\end{array}$ & $\begin{array}{c}<10 \mathrm{~km} \\
\text { (West Wales) }\end{array}$ & & $\begin{array}{c}<50 \mathrm{~km} \\
\text { (West Wales) }\end{array}$ & $\begin{array}{c}<10 \mathrm{~km} \\
\text { (West Wales) }\end{array}$ \\
\hline & $\begin{array}{c}10-50 \mathrm{~km} \\
\text { (East Wales) }\end{array}$ & $\begin{array}{c}10-20 \mathrm{~km} \\
\text { East Wales) }\end{array}$ & Wales & $\begin{array}{c}10-50 \mathrm{~km} \\
\text { (East Wales) }\end{array}$ & $\begin{array}{c}10-20 \mathrm{~km} \\
\text { (East Wales) }\end{array}$ \\
\hline
\end{tabular}

Control wards $<10 \mathrm{~km}$ from border excluded

\section{(1)}

West Wales

$(0.0222) \quad(0.0190)$

U reduction

(2)

$0.0265-0.0104$

(3)

(4)

(5)

(6)

$\begin{array}{ccc}- & 0.0275 & -0.00177 \\ 0.000430 & & \\ (0.0219) & (0.0184) & (0.0134)\end{array}$

\begin{tabular}{|c|c|c|c|c|c|c|}
\hline \multicolumn{4}{|l|}{$\begin{array}{l}\text { West Wales } x \\
U \text { decrease }\end{array}$} & $\begin{array}{c}1.382^{\star \star \star} \\
(0.372)\end{array}$ & $\begin{array}{l}0.832^{\star \star} \\
(0.390)\end{array}$ & $\begin{array}{l}1.147^{\star \star} \\
(0.492)\end{array}$ \\
\hline Controls & $\checkmark$ & $\checkmark$ & $\checkmark$ & $\checkmark$ & $\checkmark$ & $\checkmark$ \\
\hline Observations & 693 & 947 & 551 & 388 & 642 & 168 \\
\hline R-squared & 0.262 & 0.459 & 0.404 & 0.315 & 0.427 & 0.604 \\
\hline
\end{tabular}

Notes: clustered standard errors at local authority level in parenthesis. ${ }^{\star \star *} p<0.01,{ }^{\star *} p<0.05,{ }^{\star} p<0.1$. Forcing variable: distance in $\mathrm{km}$ from border between East Wales and West Wales. West Wales: dummy variable taking value 1 for all wards belonging to West Wales and The Valley. Samples: all wards of Wales excluding East Wales wards less than $10 \mathrm{~km}$ from border (columns (1), (4)), all West Wales wards located $50 \mathrm{~km}$ or less from the treatment border and East Wales wards between 10 and $50 \mathrm{~km}$ from treatment border (columns (2), (5)), all West Wales wards located $10 \mathrm{~km}$ or less from the treatment border and East Wales wards between 10 and $20 \mathrm{~km}$ from border (columns (3), (6)). Controls refer to labour market and demographic ward characteristics taken from the Census. 
EU funds, local opportunities, and the Brexit vote

Table A8. EU funds beneficiaries, unemployment reduction, and Brexit

Dep. var.: Share of Remain votes

$\begin{array}{cc}\text { Cardiff wards } & \text { Cardiff wards } \\ \text { excluded } & \text { excluded }\end{array}$

\section{(1)}

(2)

$1.80 \mathrm{e}-07$

$1.28 \mathrm{e}-07$

(3)

(3.85e-07)

(5.28e-07)

$6.84 \mathrm{e}-07 *$

(4)

EU funds beneficiaries

U decrease

EU funds beneficiaries $\mathrm{x} U$

decrease

(2.90e-07)

$5.56 \mathrm{e}-07$

(4.26e-07)

0.692

1.120

(0.847)

(0.708)

$0.000147^{* *} \quad 0.000131 *$

Controls

Observations

823

(5.90e-05)

(6.60e-05)

R-squared

0.423

0.383

831

802

0.445

0.415

Notes: clustered standard errors at local authority level in parenthesis. ${ }^{\star \star *} p<0.01,{ }^{\star} \mathrm{p}<0.05,{ }^{*} p<0.1$. Samples: all Wales wards (columns (1), (3)), all Wales wards excluding wards from Cardiff (columns (2), (4)). Controls refer to labour market and demographic ward characteristics taken from the Census. 
Table A9. EU funds, human capital, and Brexit

\begin{tabular}{|c|c|c|c|c|c|c|}
\hline \multicolumn{7}{|c|}{ Dep. var.: Share of Remain votes } \\
\hline & $\begin{array}{c}\text { Wales } \\
\text { (1) }\end{array}$ & $\begin{array}{c}<50 \mathrm{~km} \\
(2)\end{array}$ & $\begin{array}{c}<10 \mathrm{~km} \\
(3)\end{array}$ & $\begin{array}{c}\text { Wales } \\
\text { (4) }\end{array}$ & $\begin{array}{c}<50 \mathrm{~km} \\
\text { (5) }\end{array}$ & $\begin{array}{c}<10 \mathrm{~km} \\
\text { (6) }\end{array}$ \\
\hline West Wales & $\begin{array}{l}-0.00348 \\
(0.0239)\end{array}$ & $\begin{array}{l}-0.0161 \\
(0.0255)\end{array}$ & $\begin{array}{l}-0.0158 \\
(0.0251)\end{array}$ & $\begin{array}{l}-0.00703 \\
(0.0224)\end{array}$ & $\begin{array}{l}-0.00047 \\
(0.0303)\end{array}$ & $\begin{array}{l}-0.0220 \\
(0.0235)\end{array}$ \\
\hline Tertiary educated & $\begin{array}{l}0.118 * \star \\
(0.0421)\end{array}$ & $\begin{array}{l}0.217 * \star \star \\
(0.0719)\end{array}$ & $\begin{array}{l}0.148 * \star \star \\
(0.0461)\end{array}$ & $\begin{array}{l}0.133^{\star \star \star} \\
(0.0343)\end{array}$ & $\begin{array}{l}0.225^{\star \star \star} \\
(0.0724)\end{array}$ & $\begin{array}{l}0.146^{\star \star \star} \\
(0.0469)\end{array}$ \\
\hline $\begin{array}{l}\text { West Wales x Tertiary } \\
\text { educated }\end{array}$ & $\begin{array}{c}0.0890 \\
(0.0634)\end{array}$ & $\begin{array}{c}0.0260 \\
(0.0738)\end{array}$ & $\begin{array}{c}0.0683 \\
(0.0962)\end{array}$ & $\begin{array}{c}0.0321 \\
(0.0525)\end{array}$ & $\begin{array}{c}0.0357 \\
(0.0776)\end{array}$ & $\begin{array}{r}0.0643 \\
(0.0926)\end{array}$ \\
\hline Polynomial & $1-1$ & $1-1$ & $1-1$ & $3-3$ & $3-3$ & $3-3$ \\
\hline Observations & 802 & 1,057 & 415 & 802 & 1,057 & 415 \\
\hline R-squared & 0.230 & 0.260 & 0.251 & 0.416 & 0.287 & 0.257 \\
\hline $\begin{array}{l}\text { Best polynomial degree } \\
\text { (AIC) }\end{array}$ & & & & $\checkmark$ & $\checkmark$ & $\checkmark$ \\
\hline
\end{tabular}

Notes: clustered standard errors at local authority level in parenthesis. ${ }^{\star *} p<0.01,{ }^{*} p<0.05,{ }^{*} p<0.1$. Forcing variable: distance in $\mathrm{km}$ from border between East Wales and West Wales. West Wales: dummy variable taking value 1 for all wards belonging to West Wales and The Valley. Tertiary educated: 2011 ward population holding NVQ level 4 or above. Samples: all wards of Wales (columns (1),(4)), all wards located $50 \mathrm{~km}$ or less from the treatment border (columns (2),(5)), all wards located $10 \mathrm{~km}$ or less from the treatment border (columns (3),(6)). Cardiff wards excluded. Models estimated with polynomials of order one (columns (1)-(3)) or order three (columns (4)-(6)) interacted with forcing variable and treatment variable. 
Table A10. EU funds, unemployment reduction, and Brexit - results by level of human capital

Dep. var.: Share of Remain votes

\begin{tabular}{lccc|ccc} 
& \multicolumn{3}{c|}{$\begin{array}{c}\text { Human capital below median } \\
\text { (less than 26\% holding tertiary } \\
\text { education degree) }\end{array}$} & \multicolumn{3}{c}{$\begin{array}{c}\text { Human capital above median } \\
\text { (more than 26\% holding tertiary } \\
\text { education degree) }\end{array}$} \\
& Wales & $<50 \mathrm{~km}$ & $<10 \mathrm{~km}$ & Wales & $<50 \mathrm{~km}$ & $<10 \mathrm{~km}$ \\
& $(1)$ & $(2)$ & $(3)$ & $(4)$ & $(5)$ & $(6)$ \\
\hline West Wales & 0.00062 & 0.0178 & -0.0084 & 0.0154 & 0.0244 & 0.0212 \\
& $(0.0193)$ & $(0.0219)$ & $(0.0170)$ & $(0.0153)$ & $(0.0210)$ & $(0.0167)$ \\
U decrease & 0.298 & 0.722 & 0.0912 & 0.341 & 1.123 & 0.326 \\
& $(0.244)$ & $(0.645)$ & $(0.269)$ & $(0.239)$ & $(0.931)$ & $(0.305)$ \\
West Wales x U & 0.346 & $1.426 \star \star$ & 1.010 & $2.094^{\star \star \star}$ & $2.541^{\star}$ & $2.247^{\star}$ \\
decrease & $(0.418)$ & $(0.689)$ & $(0.587)$ & $(0.453)$ & $(1.381)$ & $(1.301)$ \\
& $3-3$ & $3-3$ & $3-3$ & $3-3$ & $3-3$ & $3-3$ \\
\hline Polynomial & 521 & 650 & 278 & 281 & 407 & 137 \\
Observations & 0.282 & 0.178 & 0.139 & 0.374 & 0.209 & 0.217 \\
R-squared & $\checkmark$ & $\checkmark$ & $\checkmark$ & $\checkmark$ & $\checkmark$ & $\checkmark$ \\
$\begin{array}{l}\text { Best polynomial } \\
\text { degree (AIC) }\end{array}$ & & & & & & \\
\hline \hline
\end{tabular}

Notes: clustered standard errors at local authority level in parenthesis. ${ }^{\star \star \star} p<0.01,{ }^{\star} p<0.05,{ }^{\star} p<0.1$. Forcing variable: distance in $\mathrm{km}$ from border between East Wales and West Wales. West Wales: dummy variable taking value 1 for all wards belonging to West Wales and The Valley. U decrease: ward-level unemployment rate difference between 2011 and 2001. Samples: all wards of Wales (columns (1),(4)), all wards located $50 \mathrm{~km}$ or less from the treatment border (columns (2),(5)), all wards located $10 \mathrm{~km}$ or less from the treatment border (columns (3),(6)). Cardiff wards excluded. Models estimated with polynomials of order one (columns (1)-(3)) or order three (columns (4)-(6)) interacted with forcing variable and treatment variable. 


\section{Recent LEQS papers}

D’Elia, Enrico \& De Santis, Roberta. 'Growth divergence and income inequality in OECD countries: the role of trade and financial openness' LEQS Paper No. 148, October 2019

Monnet, Eric, Pagliari, Stefano, \& Vallée, Shahin. 'Beyond financial repression and regulatory capture: the recomposition of European financial ecosystems after the crisis' LEQS Paper No. 147, September 2019

Craik, P. B. 'The Weaponization of Postmodernism: Russia's New War with Europe' LEQS Paper No. 146, July 2019

Hodson, Dermot. 'The New Intergovernmentalism and the Euro Crisis: A Painful Case?' LEQS Paper No. 145, June 2019

Codogno, Lorenzo \& van den Noord, Paul. 'The rationale for a safe asset and fiscal capacity for the Eurozone' LEQS Paper No. 144, May 2019

Simoni, Marco. 'Institutional Roots of Economic Decline: Lessons from Italy' LEQS Paper No. 143, April 2019

De Santis, Roberta. 'On Productivity Measurement and Interpretation: Some Insights on Italy in the European Context' LEQS Paper No. 142, March 2019

Avlijaš, Sonja. 'The dynamism of the new economy: Non-standard employment and access to social security in EU-28' LEQS Paper No. 141, February 2019

Besimi, Fatmir \& Monastiriotis, Vassilis. 'The Role of EU Integration in Accelerating Structural Reforms in the Western Balkans: Evidence, Theory and Policy' LEQS Paper No. 140, January 2019

Saka, Orkun \& Bircan, Çağatay. 'Lending Cycles and Real Outcomes: Costs of Political Misalignment' LEQS Paper No. 139, December 2018

Wolkenstein, Fabio. 'Transnational Partisanship and Networked Constituent Power in the EU' LEQS Paper No. 138, October 2018

Macchiarelli, Corrado 'What is the EU-UK relation all about? Tracking the path from monetary integration to "ever closeness"' LEQS Paper No. 137, September 2018

Meyer, Niclas 'EU break-up? Mapping plausible pathways into alternative futures' LEQS Paper No. 136, August 2018

Di Cataldo, Marco \& Monastiriotis, Vassilis 'An assessment of EU Cohesion Policy in the UK regions: direct effects and the dividend of targeting' LEQS Paper No. 135, June 2018

Innes, Abby 'First-best-world economic theory and the second-best-world of public sector outsourcing: the reinvention of the Soviet Kombinat by other means' LEQS Paper No. 134, May 2018

Bojar, Abel 'With a Little Help from My Friends: Ministerial Alignment and Public Spending Composition in Parliamentary Democracies' LEQS Paper No. 133, April 2018 


\section{LEQS}

European Institute London School of Economics Houghton Street WC2A 2AE London Email: euroinst.LEQS@Ise.ac.uk

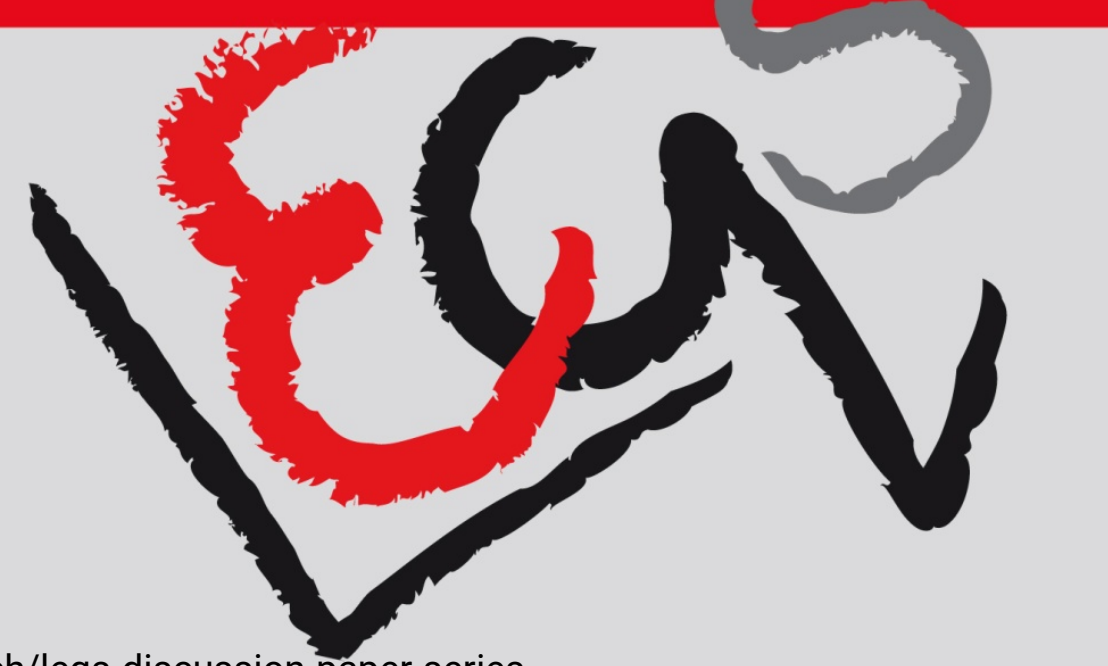

